\title{
Forty-six new species of Trypetheliaceae from the tropics
}

\author{
André APTROOT, Damien ERTZ, Javier Angel ETAYO SALAZAR, \\ Cécile GUEIDAN, Joel Alejandro MERCADO DIAZ, Felix SCHUMM \\ and Gothamie WEERAKOON
}

\begin{abstract}
The following 46 new species of Trypetheliaceae are described: Astrothelium aenascens Aptroot from Papua New Guinea, which is similar to $A$. aenoides but differs by the hamathecium which is not inspersed; $A$. alboverrucoides Aptroot from Indonesia with globose ascomata with constricted base, internally similar to $A$. megaspermum; $A$. clypeatum Aptroot \& Gueidan from Vietnam with black conical ascomata in which the pseudostroma is reminiscent of a clypeus, a rimose thallus, and 3-septate ascospores, 85-95 $\times 22-25 \mu \mathrm{m} ; A$. colombiense Aptroot from Colombia with 1 muriform ascospore of 240-300 $\times 45-50 \mu \mathrm{m}$ per ascus, and an inspersed hamathecium; $A$. condoricum Aptroot from Ecuador with a bright orange thallus and contrasting bright scarlet internal pigment, and muriform ascospores, $38-42 \times 18-21 \mu \mathrm{m} ;$ A. corallinum Aptroot from Guyana, which is most similar to $A$. ochroleucoides but the thallus is without lichexanthone; $A$. dicoloratum Aptroot from Venezuela with an orange thallus and more yellowish pseudostromata with usually only 1 ascoma, and 9-11-septate ascospores; A. ecuadoriense Aptroot from Ecuador with ascospores 2 per ascus, muriform, $80-175 \times 25-50 \mu \mathrm{m}$, and an inspersed hamathecium; A. flavomaculatum Aptroot from Ecuador, Guyana and Venezuela which is similar to $A$. graphicum, but with ascospores $50-75 \times 12-25 \mu \mathrm{m} ;$ A. flavomeristosporum Aptroot from the Philippines and Ecuador with mostly simple ascomata with an orange to yellow, inspersed hamathecium and muriform ascospores 140-200 $\times 25-30 \mu \mathrm{m} ;$ A. flavostiolatum Aptroot from Ecuador with bright yellow ostioles and a very irregular thallus, and muriform ascospores, $175-230 \times 35-45 \mu \mathrm{m}$; A. guianense Aptroot from Guyana with a very irregular thallus, eccentric, fused ostioles and ascospores 4 per ascus, muriform, 70-80 $\times 20-25 \mu \mathrm{m} ; A$. inspersogalbineum Aptroot $\&$ Weerakoon from Singapore which is similar to $A$. macrocarpum but with the hamathecium inspersed; $A$. komposchii Aptroot from Venezuela with chimney-like ostioles and a very irregular, almost squamulose thallus and muriform ascospores, $130-180 \times 35-45 \mu \mathrm{m} ; A$. laurerosphaerioides Aptroot from Guyana with aggregated ascomata with internally and partly (when abraded) also superficially orange anthraquinone pigment, ascospores 2 per ascus, muriform, 110-130 × 30-35 $\mu \mathrm{m} ;$ A. lucidomedullatum Aptroot from Ecuador with lichexanthone in the medulla of the thallus, ascospores 4 per ascus, muriform, $80-115 \times 25-35 \mu \mathrm{m}$; A. lucidostromum Aptroot from Guyana which is similar to $A$. eustomuralis but lichexanthone is present in the whole pseudostroma; $A$. lucidothallinum Aptroot from Guyana with the thallus containing lichexanthone, ascomata in pseudostromata without lichexanthone, ostioles apical, hamathecium not inspersed, ascospores muriform, $70-90 \times 18-20 \mu \mathrm{m} ; A$. mediocrassum Aptroot from Guyana which resembles $A$. octosporum but without lichexanthone in the thallus or pseudostromata, muriform ascospores, $70-80 \times 22-25 \mu \mathrm{m}$, with median septum strongly thickened; A. megatropicum Aptroot from Guyana with 3-septate ascospores 100-120 $\times 33-35 \mu \mathrm{m}$, and hemispherical dark brown pseudostromata; A. megochroleucum Aptroot from El Salvador with 3-septate ascospores $60-70 \times 16-18 \mu \mathrm{m}$ and lichexanthone in the thallus and pseudostromata; $A$. neoinspersum Aptroot from El Salvador which is similar to $A$. aenascens but with bright yellow pseudostromata; $A$. perspersum Aptroot \& Ertz from Gabon which is similar to $A$. scoria but with ascospores $26-38 \times 7-9 \mu \mathrm{m} ; A$. philippinense Aptroot $\&$ Schumm from the Philippines without pseudostromata, ostiole apical, hamathecium inspersed, ascospores muriform, 125-170 × 30-35 $\mu \mathrm{m}, 4$ per ascus; $A$. pseudannulare Aptroot \& Etayo from Ecuador with the appearance
\end{abstract}

A. Aptroot: ABL Herbarium, G.v.d. Veenstraat 107, NL-3762 XK Soest, The Netherlands. Email: andreaptroot@gmail.com

D. Ertz: Botanical Garden Meise, Department of Bryophytes-Thallophytes, Nieuwelaan 38, B-1860 Meise, Belgium.

J. A. Etayo Salazar: Navarro Villoslada 16, $3^{\circ}$ dcha., 31003 Pamplona, Navarra, Spain.

C. Gueidan: Department of Life Sciences, Natural History Museum, Cromwell Road, London
SW7 5BD, UK. Current address: CSIRO, National Facilities and Collections, National Research Collections Australia, Australian National Herbarium, P.O. Box 1600, Canberra, ACT 2601, Australia.

J. A. Mercado Diaz and G. Weerakoon: The Field Museum, 1400 South Lake Shore Drive, Chicago, Illinois 60605-2496, USA.

F. Schumm: Mozartstr. 9, D-73117 Wangen, Germany. 
of the $A$. puiggarii-group, but differing from all other species of it by the 3-septate ascospores 80-88 $\times 32-36 \mu \mathrm{m}$, which are 2-4 per ascus; $A$. pseudodissimulum Aptroot from Papua New Guinea with $\mathrm{K}+$ red crystals in the ascoma wall and 5-septate ascospores of 25-33 $\times 9-11 \mu \mathrm{m} ; A$. pseudoferrugineum Aptroot from Indonesia, of the $A$. conicum-group with an orange thallus and pseudostroma pruina, differing from $A$. ferrugineum by the ascospores $28-31 \times 9-11 \mu \mathrm{m}$ and the more glossy thallus; A. pseudomegalophthalmum Aptroot from Colombia, similar to $A$. megaspermum but differing by the 7 -septate ascospores $152-166 \times 32-37 \mu \mathrm{m} ; A$. rimosum Aptroot from Guyana and Colombia with 7-11-septate ascospores $110-150 \times 30-37 \mu \mathrm{m}$ and a rimose thallus with yellow medulla; A. sanguineoxanthum Aptroot from Brazil with the thallus containing lichexanthone and pseudostromata with numerous immersed round ascomata, the whole inside of which is full of red, $\mathrm{K}+$ green pigment; $A$. septemseptatum Aptroot from Guyana and Venezuela with the thallus and pseudostromata UV+ yellow and 7-9-septate ascospores 50-55×12-17 $\mu \mathrm{m} ; A$. sexloculatum Aptroot from Guyana and Papua New Guinea with 5-septate ascospores 25-27 $\times 7-11 \mu \mathrm{m}$ and lichexanthone in the thallus and pseudostromata; $A$. sipmanii Aptroot from Guyana with simple ascomata with 5-septate ascospores 100-150 $\times 35-40 \mu \mathrm{m}$ and an inspersed hamathecium; A. trypethelioides Aptroot from Venezuela with fused ostioles, an inspersed hamathecium and 7-9-septate ascospores 49-52 $\times 13-16 \mu \mathrm{m} ; A$. ultralucens Aptroot from Venezuela with lichexanthone in the thallus and pseudostromata, fused ostioles and 3-septate ascospores over 105-130 $\times 35-42 \mu \mathrm{m} ;$ A. vulcanum from Guyana, of the $A$. nitidiusculum-group with simple ascomata, an inspersed hamathecium and lichexanthone; A. zebrinum Aptroot from Guyana with fused ostioles and 7-septate ascospores 60-70 $\mu \mathrm{m}$ long, without lichexanthone, anthraquinones and inspersion; Polymeridium rhodopruinosum Aptroot from Puerto Rico with red pruina on the ascomata and 3-septate ascospores 17-19 $\times 3.5-5.0 \mu \mathrm{m}$; Pseudopyrenula americana Aptroot from Guyana with 3-septate ascospores $26-32 \times 7-10 \mu \mathrm{m}$, without inspersion and without lichexanthone; P. guianensis Aptroot from French Guiana and Surinam with a hyaline hamathecium with inspersion, a thallus with lichexanthone and 3-septate ascospores 21-25 $\times 6-9 \mu \mathrm{m}$; P. hexamera Aptroot from Venezuela with 5-septate ascospores 16-21 × 6-7 $\mu \mathrm{m}$, lumina clearly diamond-shaped; $P$. thallina Lücking \& Aptroot from Costa Rica with a greenish corticate thallus and 3-septate ascospores, 21-25 $\times 6-9 \mu \mathrm{m}$; Trypethelium infraeluteriae Aptroot \& Gueidan from Vietnam which is similar to T. subeluteriae but with lower pseudostromata and ascospores 7-9-septate, 37-42 ×9-11 $\mathrm{m}$; Viridothelium inspersum Aptroot from Papua New Guinea with solitary, immersed ascomata, an inspersed hamathecium, and 12-14-septate ascospores, 60-75 $\times 12-17 \mu \mathrm{m} ; V$. kinabaluense Aptroot from Sabah which is similar to V. indutum with emergent black ascomata, but with 17-25-septate ascospores 100-150 $\times 18-23 \mu \mathrm{m}$; and $V$. solomonense Aptroot from the Solomon Islands having ascomata with lateral, partly fused ostioles and black clypeus, and ascospores 15-19-septate, 75-98 $\times 17-20 \mu \mathrm{m}$. The new species are known from Brazil, Colombia, Costa Rica, Ecuador, El Salvador, Gabon, Guyana, Indonesia, Papua New Guinea, the Philippines, Puerto Rico, Sabah, Singapore, Solomon Islands, Surinam, Venezuela and/or Vietnam.

Key words: Astrothelium, Gabon, lichens, Malesia, Neotropics, Polymeridium, Pseudopyrenula, Trypethelium, Viridothelium

Accepted for publication 6 fanuary 2016

\section{Introduction}

The family Trypetheliaceae is an almost exclusively tropical corticolous lichen family. The first members were encountered at the end of the 18th century on pieces of medicinal bark (mainly Cinchona for quinine) that were collected in South American forests (Zenker 1829). The conspicuous, often brightly coloured ascomata with complex structures intrigued the lichenologists of the time. Soon afterwards, more species became known from places such as Australia, Brazil and Borneo, which were described in many separate papers, for example by Krempelhuber, Montagne and Müller Argoviensis.

Relatively few species were known for a long time, and little more than the type specimen was known from most described species. In 1986, Harris started publishing on the family, defining it in a restricted sense, and taking up a generic division that has been in use since then, although it was clear that it was largely untenable because, for example, a single specimen could partly belong to one genus and partly to another. Aptroot \& Cáceres (2014), in a revision of the genus Polymeridium, showed that many species 
in this family still await description or recognition.

This paper describes new species of Trypetheliaceae from various parts of the world, largely collected by the authors and/or by Harrie Sipman. They originate from many different countries, but many are from Ecuador, Guyana and/or Venezuela. The generic concept applied here follows the phylogenetic studies by Nelsen et al. (2014) and Lücking et al. (2016). All species are keyed out in Aptroot \& Lücking (2016).

\section{Material and Methods}

Identification and descriptive work was mostly carried out in Soest using an Olympus SZX7 stereomicroscope and an Olympus BX50 compound microscope with interference contrast, connected to a Nikon Coolpix digital camera. Sections were mounted in tap water, in which all measurements were also taken.

The chemistry of all specimens was investigated under UV light, and often a test with $10 \% \mathrm{KOH}$ was made, generally on sections. The chemistry of many specimens, including types of all newly described species, was investigated by thin-layer chromatography (TLC) using solvent A (Orange et al. 2001).

\section{The Species}

\section{Astrothelium aenascens Aptroot sp. nov.}

$$
\text { MycoBank No.: MB } 815206
$$

Astrothelium similar to $A$. aenoides Aptroot, but differing by the non-inspersed hamathecium.

Type: Papua New Guinea, Central Prov., Varirata National Park, 1981, H. Streimann E N. Naoni 15083 (CANB - holotype; ABL - isotype).

\section{(Fig. 1A)}

Thallus corticate, smooth, somewhat shiny, continuous, covering areas $\leq 5 \mathrm{~cm}$ diam., c. $0.2 \mathrm{~mm}$ thick, olive-green to olivegrey, not surrounded by a prothallus, not inducing gall formation of the host bark.

Ascomata globose, $0.8-1.2 \mathrm{~mm}$ diam., immersed in groups of $2-5$ in pseudostromata with a surface different from the thallus, which are distinctly raised above the thallus, irregular to often linear in outline, sides sloping, whitish mottled with orangish colour, inside with a cream layer containing bark tissue. Wall dark brown all around, $\leq$ c. $70 \mu \mathrm{m}$ thick. Ostioles apical, not fused, flat to concave, brown. Hamathecium inspersed with oil globules. Asci with 8 ascospores. Ascospores hyaline, 3-septate, fusiform, 20-25× 6-9 $\mu \mathrm{m}$, ends rounded, lumina diamondshaped, not surrounded by a gelatinous layer.

Chemistry. Thallus surface UV-, thallus medulla $\mathrm{K}-$; pseudostroma surface UV+ pink to orange, medulla of pseudostromata $\mathrm{K}+$ blood red. TLC: an anthraquinone, probably parietin.

Ecology and distribution. On smooth bark of trees in rainforest. Known only from Papua New Guinea.

Discussion. This species is similar to $A$. aenoides, which differs by the inspersed hamathecium. Both are named after the somewhat reminiscent species $A$. aeneum (Eschw.) Aptroot \& Lücking, which mainly differs by the orange pigment on the thallus.

\section{Astrothelium alboverrucoides Aptroot sp. nov.}

MycoBank No.: MB 815207

Astrothelium with globose ascomata with constricted base; internally similar to $A$. megaspermum (Mont.) Aptroot \& Lücking.

Type: Indonesia, Sumatra, Aceh, $35 \mathrm{~km} \mathrm{NNW} \mathrm{of}$ Kutacane, alt. $800 \mathrm{~m}, 1988$, R. Hensen (ABL-holotype).

(Fig. 1B)

Thallus corticate, smooth, somewhat shiny, continuous, greyish green, covering areas $\leq 4 \mathrm{~cm}$ diam., c. $0 \cdot 2 \mathrm{~mm}$ thick, surrounded by a black prothallus line c. $0.4 \mathrm{~mm}$ wide, not inducing gall formation of the host bark.

Ascomata globose, $0.8-1.4 \mathrm{~mm}$ diam., mostly single, occasionally 2 aggregated, in almost globose pseudostromata of thallus colour or more greyish, with often constricted base. Wall carbonized, $\leq c .120 \mu \mathrm{m}$ thick. Ostioles apical, not fused, pointed, ochraceous to brown. Hamathecium inspersed with oil globules. Asci with 4 ascospores. Ascospores hyaline, muriform, ellipsoid, 140-190 $\times 20-30 \mu \mathrm{m}$, with 

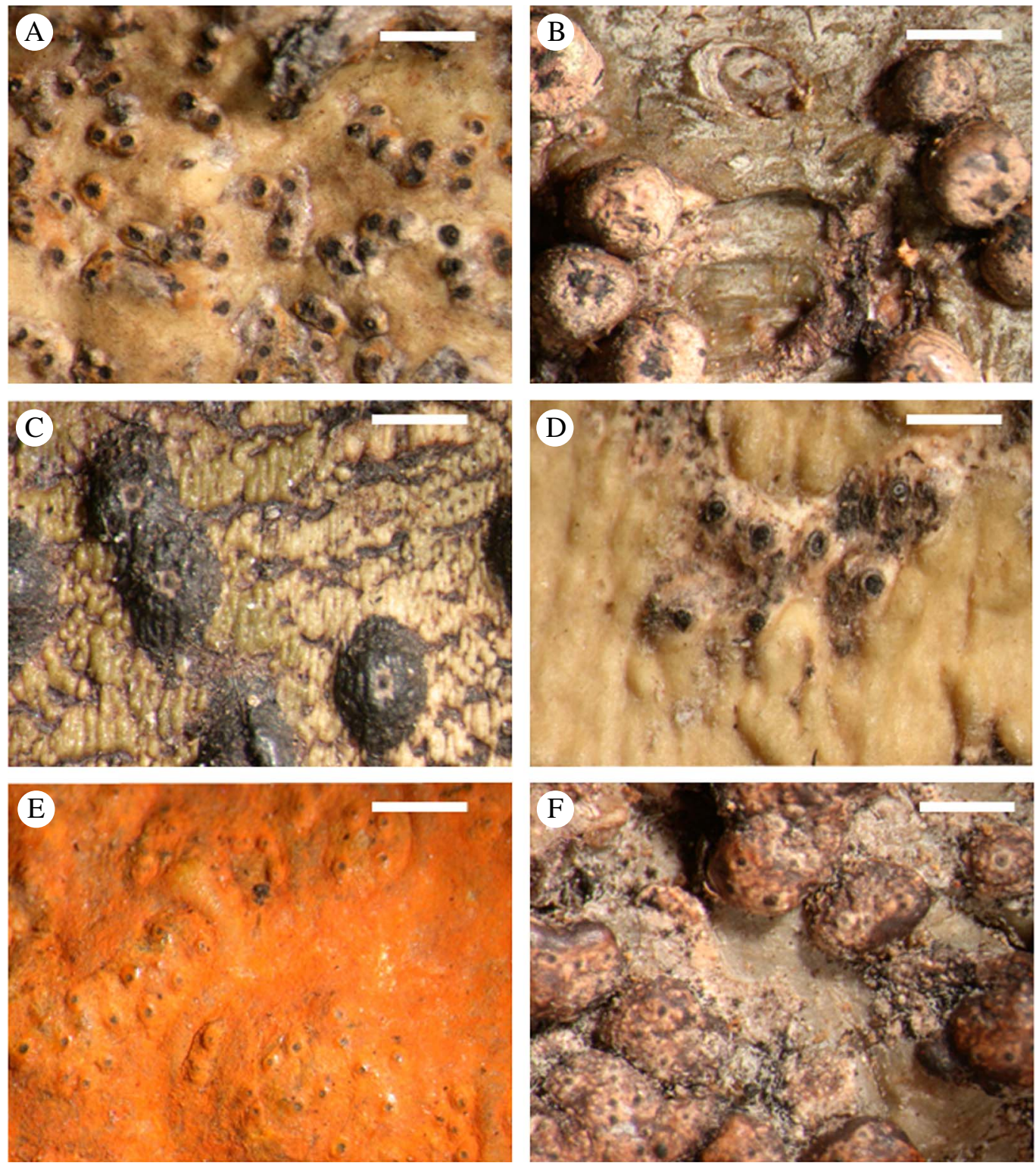

FIG. 1. Habitus of new species of Trypetheliaceae (holotypes). A, Astrothelium aenascens; B, A. alboverrucoides; C, A. clypeatum; D, A. colombiense; E, A. condoricum; F, A. corallinum. Scales: A-F $=1 \mathrm{~mm}$. In colour online.

a distinctly thickened median septum, ends rounded, not surrounded by a gelatinous layer. Pycnidia not observed.

Chemistry. Thallus and pseudostromata $\mathrm{K}-$, UV-. TLC: no secondary substances detected.
Ecology and distribution. On smooth bark of trees in rainforest. Known only from Indonesia.

Discussion. This species is characterized by the globose ascomata with constricted base; internally it is similar to $A$. megaspermum, the 
ascospores of which are, however, usually wider than $30 \mu \mathrm{m}$.

\section{Astrothelium clypeatum Aptroot \& Gueidan sp. nov.}

MycoBank No.: MB 815208

Astrothelium with black conical ascomata, pseudostromata reminiscent of a clypeus, with a rimose thallus and 3-septate ascospores, 85-95 × 22-25 $\mu \mathrm{m}$.

Type: Vietnam, Dong Nai Prov., Cát Tiên National Park, along the road towards the Forest Ecolodge, 12 February 2012, C. Gueidan 3005 (BMholotype).

(Fig. 1C)

Thallus olive-green, somewhat minutely rimose-bullate and interspersed with branched lines of black prothallus.

Ascomata conical in section, black, thinwalled, single, fully immersed in pseudostromata. Pseudostromata $0 \cdot 8-1.3 \mathrm{~mm}$ diam., superficial, carbonized, conical with flattened top, resembling a clypeus, without pigment, but a zone with bark colour and tissue is present between the ascoma and the clypeus. Wall carbonized, $\leq 220 \mu \mathrm{m}$ at the sides, carbonized all around. Ostioles apical, rusty brown, surrounded by an ochraceous ring. Hamathecium inspersed with hyaline oil droplets, filaments profusely anastomosing. Ascospores 8 per ascus, 3-septate, $\quad 85-95 \times 22-25 \mu \mathrm{m}$, lumina diamond-shaped.

Chemistry. Thallus and pseudostromata UV-, K-. TLC: no secondary substances detected.

Ecology and distribution. On bark of trees along a road. Known only from Vietnam.

Discussion. This species is anomalous owing to the black conical ascomata in which the pseudostroma is a clypeus. It is described here in the genus Astrothelium because of the well-developed, corticate, rimose thallus, but it could also turn out to belong to Pseudopyrenula.

\section{Astrothelium colombiense Aptroot sp. nov.}

MycoBank No.: MB 815209

Astrothelium with 1 muriform ascospore of $240-300 \times$ 45-50 $\mu \mathrm{m}$ per ascus, and an inspersed hamathecium.

Type: Colombia, Nariño, Tumaco, Estacion Forestal La Espriella, alt. 35 m, 4-6 June 1986, H. F. M. Sipman $\mathcal{E} F$. Velosa 33018 (B-holotype).

\section{(Fig. 1D)}

Thallus corticate, smooth to somewhat rugose, shiny, covering areas $\leq 10 \mathrm{~cm}$ diam., c. $0.2 \mathrm{~mm}$ thick, pale ochraceous green, not surrounded by a prothallus, not inducing gall formation of the host bark.

Ascomata pyriform, 0.6-0.9 mm diam., solitary, completely immersed in the bark, below decorticated flat areas that are flush with the thallus but can be seen as ochraceous white pseudostromata. Wall carbonized all around, $\leq c .80 \mu \mathrm{m}$ thick. Ostioles apical, simple, flat to convex, black, often surrounded by an ochraceous ring, presenting the only part of the ascoma that is visble from above. Hamathecium inspersed with oil globules. Asci with 1 ascospore. Ascospores hyaline, muriform, 240-300 × 45-50 $\mu \mathrm{m}$, ellipsoid, without distinctly thickened median septum.

Pycnidia not observed with certainty, although some of the many black dots around the ostioles may represent young pycnidia.

Chemistry. Thallus and pseudostromata UV-, K-. TLC: no secondary substances detected.

Ecology and distribution. On smooth bark of trees in rainforest. Known only from Colombia.

Discussion. This is one of the very few Astrothelium species with only 1 ascospore in the ascus, and the only one with ascospores usually over $250 \mu \mathrm{m}$ and with an inspersed hamathecium.

Additional material examined. Colombia: same data as the type, 33022 (B, topotype). 


\section{Astrothelium condoricum Aptroot sp. nov.}

MycoBank No.: MB 815210

Astrothelium with a bright orange thallus and contrasting bright scarlet internal pigment, and muriform ascospores, 38-42 × 18-21 $\mu \mathrm{m}$.

Type: Ecuador, Morona-Santiago Prov., Cordillera del Condor, $12 \mathrm{~km} \mathrm{E}$ of Los Encuentros, alt. $1200 \mathrm{~m}$, 26 July 1982, A. Aptroot 10452 (ABL-holotype).

\section{(Fig. 1E)}

Thallus dull, completely covered with bright orange pigment, not surrounded by a prothallus, not inducing gall formation of the host bark.

Ascomata globose, immersed in low pseudostroma warts, in groups of 3-11. Pseudostromata orange-pigmented on the surface, internally with a thick layer of bright scarlet pigment. Ostioles apical, mostly orange. Hamathecium not inspersed, IKI- . Ascospores 8 per ascus, hyaline, muriform, 38-42 × 18-21 $\mathrm{m}$, ellipsoid, without distinctly thickened median septum.

Chemistry. Orange pigment $\mathrm{K}+$ purple, $\mathrm{UV}+$ red; bright scarlet internal pigment $\mathrm{K}+$ purple (almost black). TLC: two anthraquinones.

Ecology and distribution. On smooth bark of trees in mountain forest. Known only from Ecuador.

Discussion. Unmistakable by the bright orange thallus and the contrasting bright scarlet internal pigment.

Additional material examined. Ecuador: same data as the type, 10451 (ABL, topotype).

\section{Astrothelium corallinum Aptroot sp. nov.}

MycoBank No.: MB 815211

Astrothelium which is most similar to A. ochroleucoides Aptroot \& M. Cáceres, but without lichexanthone in the thallus.

Type: Guyana, Upper Mazaruni Distr., Paruima Mission, Rain Mountain SE of the village, alt. $500 \mathrm{~m}$, 30 April 1997, H. F. M. Sipman 39574 (B-holotype).
(Fig. 1F)

Thallus corticate, smooth, somewhat shiny, continuous, covering areas $\leq 8 \mathrm{~cm}$ diam., c. $0 \cdot 1 \mathrm{~mm}$ thick, olive-green, surrounded by a black prothallus line c. $0.3 \mathrm{~mm}$ wide, not inducing gall formation of the host bark.

Ascomata globose, $0.4-0.6 \mathrm{~mm}$ diam., immersed in groups of c. 2-40 in pseudostromata. Pseudostromata with a surface different from the thallus, c. $0.5-1.0 \mathrm{~mm}$ raised above the thallus, oval to irregular or reticulate in outline, $\leq c .3 \mathrm{~mm}$ wide, brownish black, usually partly with whitish cover, partly brownish, partly whitish inside. Wall dark brown all around, $\leq c$. $40 \mu \mathrm{m}$ thick. Ostioles apical, not fused, flat to convex, brown. Hamathecium not inspersed with oil globules. Asci with 8 ascospores. Ascospores hyaline, muriform, fusiform, 60-150 × 15-30 $\mu \mathrm{m}$, ends rounded, not surrounded by a gelatinous layer, central septum not strongly thickened.

Pycnidia not observed.

Chemistry. Thallus surface UV-, thallus medulla $\mathrm{K}-$; whitish parts of pseudostroma surface UV+ yellow, $\mathrm{K}-$, pseudostroma medulla K-. TLC: lichexanthone.

Ecology and distribution. On smooth bark of trees in rainforest. Known only from Guyana.

Discussion. This species is most similar to A. ochroleucoides, which differs by the UV+ yellow thallus. These two species grow together in close contact in Guyana.

Additional material seen. Guyana: East Demarara Distr.: Timehri, Dakara Creek, Thompson's farm, 1985, Sipman \& Aptroot 18040 \& 18052 (B). Potaro-Siparuni Region: surroundings of Paramakatoi village, alt. $800 \mathrm{~m}$, 1996, Sipman 41275 p.p. (B).

\section{Astrothelium dicoloratum Aptroot sp. nov.}

\section{MycoBank No.: MB 815212}

Astrothelium with an orange thallus and more yellowish pseudostromata with usually only 1 ascoma, and 9-11-septate ascospores.

Type: Venezuela, Amazonas, Alto Orinoco, c. $15 \mathrm{~km}$ SW of La Esmeralda, W bank of Surumoni, on Goupia 
glabra, alt. $110 \mathrm{~m}, 15$ February 1997, f. Hafellner $\mathcal{E}$ H. Komposch 209-6-50 (GZU-holotype).

(Fig. 2A)

Thallus dull, completely covered with bright orange pigment, not surrounded by a prothallus, not inducing gall formation of the host bark.

Ascomata pyriform, $0.6-0.9 \mathrm{~mm}$ diam., solitary or occasionally $2-5$ fused, completely immersed to emergent from the bark, in yellow-orange to ochraceous pseudostromata. Wall carbonized all around, $\leq c .80 \mu \mathrm{m}$ thick. Ostioles apical, simple, flat to convex, black, often surrounded by an ochraceous ring, again surrounded by a black ring in the case of emergent ascomata. Hamathecium inspersed with oil globules. Asci with 1 ascospore. Ascospores hyaline,

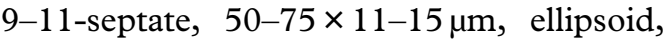
without distinctly thickened median septum.

Pycnidia not observed with certainty, although some of the many black dots around the ostioles may represent young pycnidia.

Chemistry. Thallus and pseudostromata $\mathrm{UV}+$ red, $\mathrm{K}+$ purple. TLC: an anthraquinone.

Ecology and distribution. On smooth bark of trees in rainforest. Known only from Venezuela.

Discussion. Characterized by the orange thallus and more yellowish pseudostromata with usually only 1 ascoma, and the 9-11septate ascospores; it is the only species with 9-11-septate ascospores that has an orange thallus.

Additional material examined. Venezuela: same locality as the type, 1997, $\mathcal{F}$. Hafellner $\mathcal{E}$ H. Komposch 318-548, 178-5-44, 178-5-23; 1996, F. Hafellner 37440; $1 \mathrm{~km} \mathrm{~N}$ of Estácion A. de Humboldt, 15 iii 1996, K. Fetzsch (all GZU).

\section{Astrothelium ecuadoriense Aptroot sp. nov.}

MycoBank No.: MB 815213

Astrothelium with ascospores 2 per ascus, muriform, 80-175 $\times 25-50 \mu \mathrm{m}$, and an inspersed hamathecium.
Type: Ecuador, Zamora-Chinchipe, Estacion Cientifico San Francisco, $40 \mathrm{~km} \mathrm{~S}$ of Loja, 16 May 2004, H. F. M. Sipman 52318 (B-holotype).

\section{(Fig. 2B)}

Thallus corticate, very smooth, shiny, covering areas $\leq 10 \mathrm{~cm}$ diam., c. $0.3 \mathrm{~mm}$ thick, pale ochraceous green, not surrounded by a prothallus, not inducing gall formation of the host bark.

Ascomata pyriform, $0.6-1.2 \mathrm{~mm}$ diam., solitary, completely immersed to emergent from the bark and then the black wall partly exposed, without pseudostromata. Wall carbonized all around, $\leq c$. $100 \mu \mathrm{m}$ thick. Ostioles mostly eccentric, simple, concave, brown, surrounded by an ochraceous ring, presenting the only part of the ascoma that is visble from above. Hamathecium inspersed with oil globules. Asci with 2 ascospores. Ascospores hyaline, muriform, 80-175 $\times 25-50 \mu \mathrm{m}$, ellipsoid, without distinctly thickened median septum.

Chemistry. Thallus UV-, K-. No substances detected.

Ecology and distribution. On smooth bark of trees in mountain forest. Known only from Ecuador.

Discussion. This is one of the few Astrothelium species with only 2 ascospores in the ascus, and the only one with large ascospores and an inspersed hamathecium, except for $A$. pyrenuliforme Flakus \& Aptroot, which has pseudocyphellae.

\section{Astrotheliuma flavomaculatum Aptroot sp. nov.}

MycoBank No.: MB 815214

Astrothelium similar to $A$. graphicum Aptroot \& S. M. A. Martins, but with ascospores $50-75 \times 12-25 \mu \mathrm{m}$.

Type: Ecuador, Morona-Santiago Prov., Cordillera del Condor, $12 \mathrm{~km}$ E of Los Encuentros, alt. $1200 \mathrm{~m}$, 26 July 1982, A. Aptroot 10441 (ABL-holotype).

(Fig. 2C)

Thallus corticate, smooth to somewhat bullate, somewhat shiny, continuous, covering 

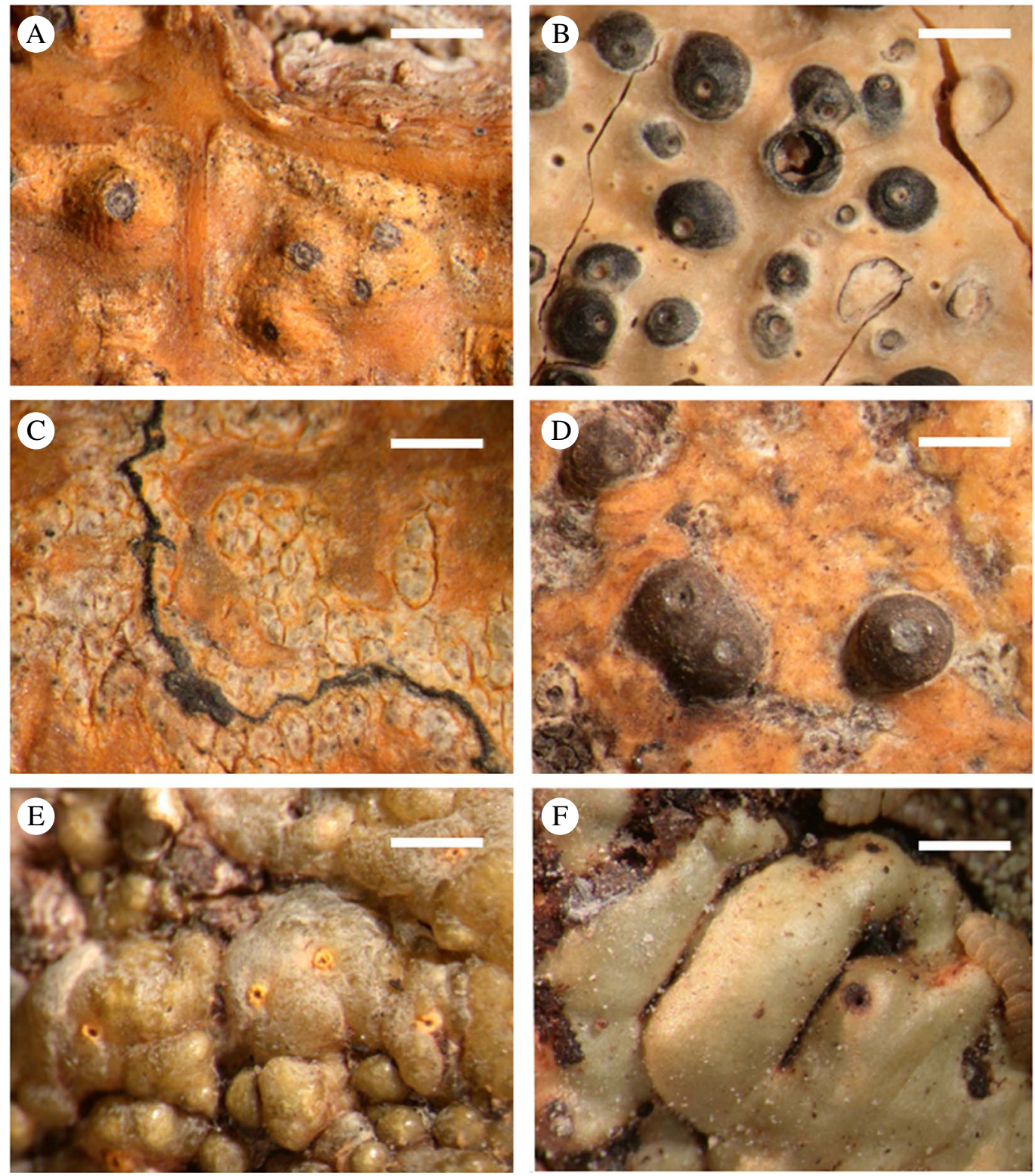

FIG. 2. Habitus of new species of Trypetheliaceae (holotypes). A, Astrothelium dicoloratum; B, A. ecuadoriense; C, A. flavomaculatum; D, A. flavomeristosporum; E, A. flavostiolatum; F, A. guianense. Scales: A-F = $1 \mathrm{~mm}$. In colour online.

areas $\leq 4 \mathrm{~cm}$ diam., c. $0 \cdot 1 \mathrm{~mm}$ thick, green with thin orange pruina, not surrounded by prothallus, not inducing gall formation of the host bark.

Ascomata globose, $0.3-0.4 \mathrm{~mm}$ diam., mostly aggregated $20-80$, immersed in or even below pseudostromata with a surface different from the thallus, which are not or not much higher than the thallus, irregular in outline, anastomosing to meandering in a reticulate pattern, $\leq c .5 \mathrm{~mm}$ diam. (but total network covering $c .50 \%$ of the whole 
thallus), ochraceous with thin orange pruina, inside ochraceous, not containing bark tissue, but ascomata often immersed in the bark. Wall carbonized, $\leq c .80 \mu \mathrm{m}$ thick. Ostioles apical, not fused, flat, ochraceous to brown. Hamathecium not inspersed with oil globules. Asci with 8 ascospores. Ascospores hyaline, muriform, ellipsoid, $50-75 \times 12-25 \mu \mathrm{m}$, without distinctly thickened median septum, ends rather pointed, not surrounded by a gelatinous layer.

Chemistry. Thallus and pseudostromata $\mathrm{UV}-$; orange pigment $\mathrm{K}+$ purple, $\mathrm{UV}+$ red. TLC: an anthraquinone.

Ecology and distribution. On smooth bark of trees in rainforest. Known from Guyana, Venezuela, and Ecuador.

Discussion. This species is similar to A. graphicum, which generally has smaller ascospores, reaching $\leq 66 \mu \mathrm{m}$.

Additional specimens seen. Guyana: Upper Takutu Distr.: Kuyuwini Landing, 1992, H. F. M. Sipman 58044 (B); Marudi Mts., NorMan Mines camp, alt. $300 \mathrm{~m}, 1982$, F. Stoffers et al. 251 (B).-Venezuela: Bolivar: Cerro Guaiquinima, along Rio Carapo, alt. 800 m, 1990, H. F. M. Sipman 26961 (B).

\section{Astrothelium flavomeristosporum Aptroot sp. nov.}

MycoBank No.: MB 815215

Astrothelium with mostly simple ascomata with an orange to yellow, inspersed hamathecium and muriform ascospores of $140-200 \times 25-30 \mu \mathrm{m}$.

Type: Philippines, Luzon, Sorsogon, Irosin, June 1916, E. Elmer 15788b (B-holotype).

(Fig. 2D)

Thallus corticate, smooth, somewhat shiny, continuous, greyish green, covering areas $\leq 9 \mathrm{~cm}$ diam., c. $0.2 \mathrm{~mm}$ thick, surrounded by a black prothallus line $c .0 \cdot 1 \mathrm{~mm}$ wide, not inducing gall formation of the host bark.

Ascomata globose, $0.8-1.2 \mathrm{~mm}$ diam., mostly single, occasionally 2 aggregated, in hemispherical brown pseudostromata without thallus cover. Wall carbonized, $\leq c .120 \mu \mathrm{m}$ thick. Ostioles apical, concave, ochraceous to brown. Hamathecium yellow to orange (at least partly), inspersed with oil globules. Asci with 4-8 ascospores. Ascospores hyaline, muriform, ellipsoid, 140-200 $\times$ 25-30 $\mu \mathrm{m}$, with distinctly thickened median septum, ends rounded, not surrounded by a gelatinous layer.

Chemistry. Thallus and pseudostromata $\mathrm{K}-$, UV-. TLC: no secondary substances detected.

Ecology and distribution. On smooth bark of trees in rainforest. Known from Ecuador and the Philippines.

Discussion. Unmistakable among Astrothelium species with simple ascomata and muriform ascospores because of the orange to yellow, inspersed hamathecium.

Additional material seen. Ecuador: Prov. ZamoraChinchipe: Cordillera Numbala, reserva Biologica San Francisco, 2003, H. F. M. Sipman E E. Mandl 51363 (B).

\section{Astrothelium flavostiolatum Aptroot sp. nov.}

MycoBank No.: MB 815216

Astrothelium with bright yellow ostioles, a very irregular thallus and muriform ascospores, $175-230 \times 35-45 \mu \mathrm{m}$.

Type: Ecuador, Zamora-Chinchipe, Cordillera Numbala, reserva Biologica San Francisco, alt. 2020 m, 24 June 2004, H. F. M. Sipman 52934 (B-holotype).

\section{(Fig. 2E)}

Thallus corticate, discontinuous, consisting of hemispherical warts or irregularly sinuose to moniliform rows of globose to slightly flattened bullate areas that fuse together to form a continuous thallus, with a hyaline cortex, covering areas $\leq 10 \mathrm{~cm}$ diam., olive-green, not surrounded by a prothallus, not inducing gall formation of the bark.

Ascomata almost globose, $0.8-1.3 \mathrm{~mm}$ diam., single, immersed in the bark below 
raised parts of the thallus. Wall carbonized, $\leq c .90 \mu \mathrm{m}$ thick. Ostioles apical to rarely eccentric, not fused, erumpent, bright yellow, chimney-like. Hamathecium inspersed with oil globules. Asci with 8 ascospores. Ascospores hyaline, muriform, fusiform, $175-230 \times 35-45 \mu \mathrm{m}$, bent, ends rounded, without markedly thickened median septum, without gelatinous sheath.

Chemistry. Thallus surface UV-, thallus medulla $\mathrm{K}-$; ostiole $\mathrm{K}+$ red. TLC: a yellow anthraquinone.

Ecology and distribution. On smooth bark of trees in rainforest. Known only from Ecuador.

Discussion. This species is characterized within Astrothelium by its muriform ascospores, bright yellow ostioles and a very irregular thallus.

\section{Astrothelium guianense Aptroot sp. nov.}

MycoBank No.: MB 815217

Astrothelium with a very irregular thallus, eccentric, fused ostioles and ascospores 4 per ascus, muriform, $70-80 \times 20-25 \mu \mathrm{m}$.

Type: Guyana, Upper Mazaruni distr., Pakaraima Mountains, $2 \mathrm{~km}$ NW of Kamarang, 4 February 1985, H. F. M. Sipman \& A. Aptroot 18261 (B-holotype; ABL-isotype).

(Fig. 2F)

Thallus corticate, discontinuous, consisting of irregularly sinuose to moniliform rows of globose to slightly flattened bullate areas that fuse together to form a continuous thallus, with a thick hyaline cortex, covering areas $\leq$ at least $6 \mathrm{~cm}$ diam., olive-green, prothallus not observed, inducing irregular gall formation of the bark which splits and deforms below the thallus.

Ascomata almost globose, $0.8-1.3 \mathrm{~mm}$ diam., single, immersed in the bark below raised parts of the thallus. Wall carbonized, $\leq c . \quad 100 \mu \mathrm{m}$ thick. Ostioles eccentric, often fused, inconspicuous. Hamathecium not inspersed with oil globules. Asci with
4 ascospores. Ascospores hyaline, muriform, fusiform, $70-80 \times 20-25 \mu \mathrm{m}$, ends pointed, outer wall thick, without markedly thickened median septum, without gelatinous sheath.

Chemistry. Thallus and pseudostromata UV-, K-. TLC: no secondary substances detected.

Ecology and distribution. On smooth bark of trees in rainforest. Known only from Guyana.

Discussion. This species is characterized by a very irregular thallus and small muriform ascospores $70-80 \times 20-25 \mu \mathrm{m}$. It is the only Astrothelium species with 4 muriform ascospores per ascus, eccentric fused ostioles and without hamathecium inspersion.

\section{Astrothelium inspersogalbineum Aptroot \& Weerakoon sp. nov.}

MycoBank No.: MB 815218

Astrothelium similar to A. macrocarpum (Fée) Aptroot \& Lücking, but hamathecium inspersed.

Type: Singapore, 20 April 2012, G. Weerakoon 118 (ABL-holotype).

\section{(Fig. 3A)}

Thallus corticate, smooth, somewhat shiny, continuous, covering areas $\leq 3 \mathrm{~cm}$ diam., c. $0.2 \mathrm{~mm}$ thick, pale greenish grey, with a black prothallus line $c .0 .2 \mathrm{~mm}$ wide, not inducing galls of the host bark.

Ascomata pyriform, c. $0.4-0.7 \mathrm{~mm}$ diam., mostly aggregated $4-10$, mostly immersed in the bark tissue below pseudostromata with orange surface different from the thallus, which are distinctly raised above the thallus, mostly roundish in outline and $\leq 2 \mathrm{~mm}$ wide. Wall carbonized, $\leq c .40 \mu \mathrm{m}$ thick. Ostioles eccentric, fused, flat, black, surrounded by a whitish zone. Hamathecium inspersed with oil globules. Asci with 8 ascospores. Ascospores hyaline, 3-septate, 22-25 $\times 9-11 \mu \mathrm{m}$, fusiform, ends pointed, lumina diamond-shaped, not surrounded by a gelatinous layer. 

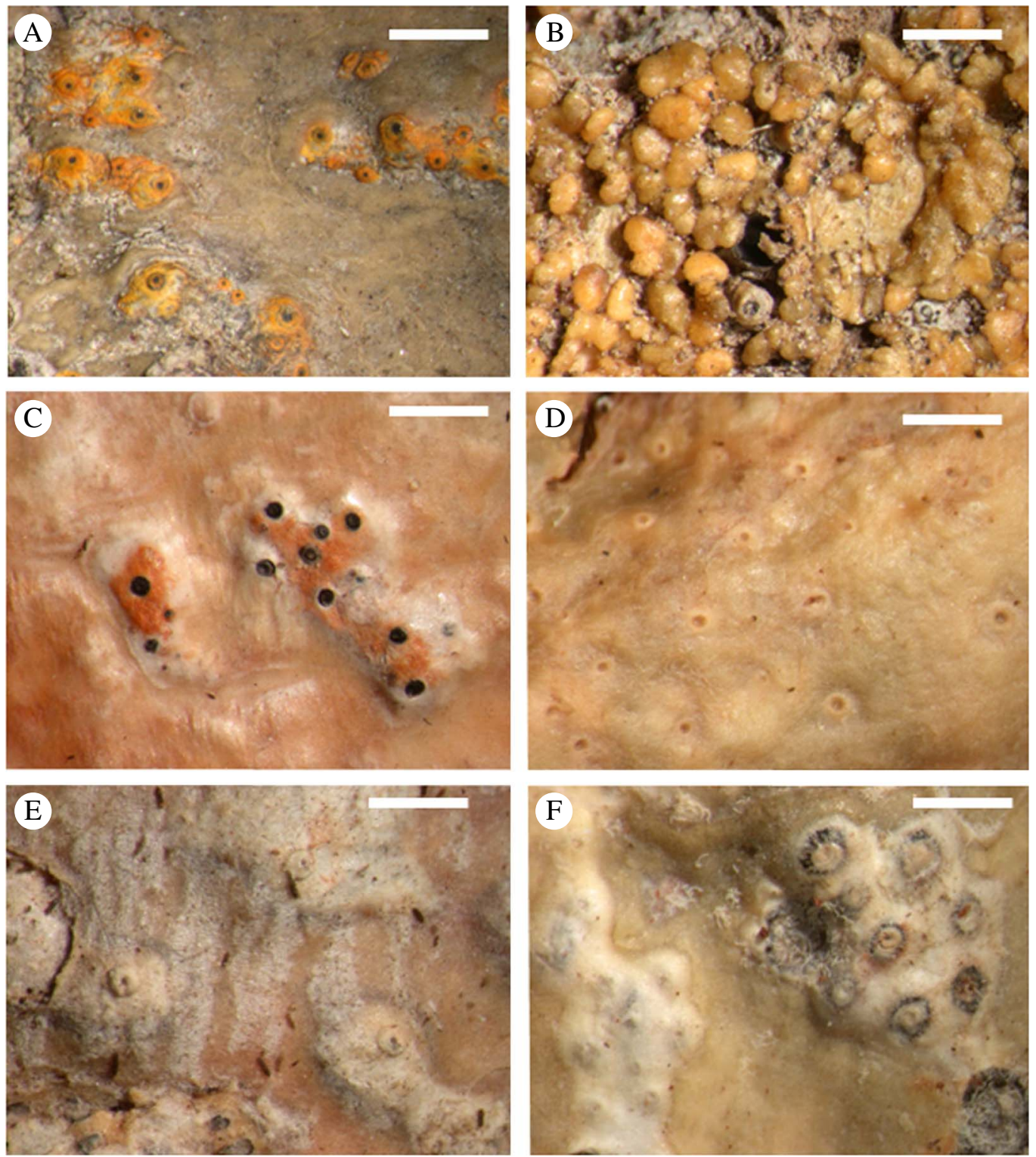

FIg. 3. Habitus of new species of Trypetheliaceae (holotypes). A, Astrothelium inspersogalbineum; B, A. komposchii; C, A. laurerosphaerioides; D, A. lucidomedullatum; E, A. lucidostromum; F, A. lucidothallinum. Scales: A-F = $1 \mathrm{~mm}$. In colour online.

Chemistry. Thallus UV+ yellow, $\mathrm{K}-$, with lichexanthone; pseudostromata $\mathrm{K}+$ purple, $\mathrm{UV}+$ red. TLC: a yellow to orange anthraquinone.

Ecology and distribution. On smooth bark of trees in rainforest. Known only from Singapore.
Discussion. This is the only member of the the core group of the genus, the Astrothelium conicum-group, with an inspersed hamathecium. Other species of the group are very numerous and often abundant, and they are never inspersed. The new species is similar to 
A. macrocarpum, which was for a long time known as $A$. galbineum Krempelh.

\section{Astrothelium komposchii Aptroot sp. nov.}

MycoBank No.: MB 815219

Astrothelium with chimney-like ostioles, a very irregular, almost squamulose thallus and muriform ascospores, $130-180 \times 35-45 \mu \mathrm{m}$.

Type: Venezuela, Amazonas, Alto Orinoco, c. $15 \mathrm{~km}$ SW of La Esmeralda, W bank of Surumoni, on Goupia glabra, alt. $110 \mathrm{~m}, 1997$, F. Hafellner \& H. Komposch 539-2-20 (GZU-holotype).

(Fig. 3B)

Thallus green, discontinuous, consisting of irregularly sinuose to moniliform rows of flattened, almost squamulose thallus lobes which mostly consist of a hyaline cortex $\leq 150 \mu \mathrm{m}$, not surrounded by a prothallus, not inducing gall formation of the bark.

Ascomata almost globose, $0.8-1.3 \mathrm{~mm}$ diam., single, immersed in the bark below raised parts of the thallus. Wall carbonized, $\leq c .90 \mu \mathrm{m}$ thick. Ostioles apical to rarely eccentric, not fused, erumpent, chimneylike, glossy olive-brown outside, black inside. Hamathecium inspersed with oil globules. Asci with 8 ascospores. Ascospores hyaline, muriform, fusiform, 130-180 × 35-45 $\mu \mathrm{m}$, bent, ends rounded, with a markedly thickened median septum, without gelatinous sheath.

Chemistry. Thallus and pseudostromata UV-, K-. TLC: no secondary substances detected.

Ecology and distribution. On smooth bark of trees in rainforest. Known only from Venezuela.

Discussion. This species is characterized by chimney-like ostioles, very irregular almost squamulose thallus, and 8 muriform ascospores per ascus.

Additional material seen. Venezuela: same data as type material, all 1997, 539-2-20, 313-3-16, 539-4-12,
991-5-15, 313-4-14, 170-5-30, 170-6-6, 170-6-19, 313-5-64, 539-6-11, 539-5-50 (all GZU).

\section{Astrothelium laurerosphaerioides Aptroot sp. nov.}

MycoBank No.: MB 815220

Astrothelium with aggregated ascomata with internally and partly (when abraded) also superficially orange anthraquinone, ascospores 2 per ascus, muriform, $110-130 \times 30-35 \mu \mathrm{m}$.

Type: Guyana, Upper Takutu Distr., Rupununi Savannah, Kusad Mountain, alt. 450 m, 29 September 1992, H. F. M. Sipman 57835 (B-holotype).

\section{(Fig. 3C)}

Thallus corticate, smooth, shiny, covering areas $\leq 15 \mathrm{~cm}$ diam., c. $0.1 \mathrm{~mm}$ thick, pale ochraceous green, not surrounded by a prothallus, not inducing gall formation of the host bark.

Ascomata pyriform, $0.6-0.9 \mathrm{~mm}$ diam., mostly aggregated 3-7, completely immersed to erumpent from the bark (and then often partly exposing the black wall), below decorticated flat, internally and partly (when abraded) also superficially orange pseudostromata that are slightly raised above the thallus. Wall carbonized all around, $\leq$ c. $80 \mu \mathrm{m}$ thick. Ostioles apical, simple, flat to concave, black. Hamathecium not inspersed with oil globules. Asci with 2 ascospores. Ascospores hyaline, muriform, 110-130 $\times 30$ $35 \mu \mathrm{m}$, ellipsoid, without distinctly thickened median septum.

Chemistry. Thallus UV-, K-; medulla and sometimes surface of pseudostromata $\mathrm{K}+$ purple. TLC: an anthraquinone.

Ecology and distribution. On smooth bark of trees in savannah forest. Known only from Guyana.

Discussion. This is the only Astrothelium with an orange anthraquinone in the pseudostroma medulla and ascospores which are 2 per ascus and muriform. 


\section{Astrothelium lucidomedullatum Aptroot sp. nov.}

MycoBank No.: MB 815221

Astrothelium with lichexanthone in the medulla of the thallus, ascospores 4 per ascus, muriform, 80-115 $\times$ 25-35 $\mu \mathrm{m}$.

Type: Ecuador, Zamora-Chinchipe, Cordillera Numbala, reserva Biologica San Francisco, alt. $2025 \mathrm{~m}, 16$ June 2004, H. F. M. Sipman 52318a (B-holotype).

(Fig. 3D)

Thallus corticate, very smooth, shiny, covering areas $\leq 5 \mathrm{~cm}$ diam., c. $0.3 \mathrm{~mm}$ thick, pale ochraceous green, not surrounded by a prothallus, not inducing gall formation of the host bark.

Ascomata pyriform, 0.6-1.2 mm diam., solitary, completely immersed in the bark, without pseudostromata. Wall pale to partly dark brown, $\leq c .70 \mu \mathrm{m}$ thick. Ostioles eccentric, simple, concave, pale brown, surrounded by an ochraceous ring, presenting the only part of the ascoma that is visible from above. Hamathecium inspersed with oil globules. Asci with 4 ascospores. Ascospores hyaline, muriform, 80-115 $\times 25-35 \mu \mathrm{m}$, ellipsoid, without a distinctly thickened median septum.

Chemistry. Thallus UV-, $\mathrm{K}-$, thallus medulla UV+ yellow, visible through the hyaline cortex. TLC: lichexanthone in the medulla (not in the cortex as usual).

Ecology and distribution. On smooth bark of trees in rainforest. Known only from Ecuador.

Discussion. The presence of lichexanthone in the medulla rather than in the cortex is probably unique in the family. It is rare in other lichen families too, otherwise known only from Megalotremis infernalis (Mont.) Aptroot and a few macrolichens.

Additional material seen. Ecuador: same locality as the type, 2004, H. F. M. Sipman 52318b (B); 2004, Sipman 52452 (B).

\section{Astrothelium lucidostromum Aptroot sp. nov.}

MycoBank No.: MB 815222

Astrothelium similar to A. eustomuralis Aptroot \& M. Cáceres, but with lichexanthone present in the whole pseudostroma.

Type: Guyana, Upper Takutu Distr., c. $45 \mathrm{~km} \mathrm{~S}$ of Aishalton, $3 \mathrm{~km} \mathrm{~S}$ of Kuyuwini Landing, alt. $230 \mathrm{~m}$, 29 October 1992, H. f. M. Sipman 57013 (B-holotype).

\section{(Fig. 3E)}

Thallus corticate, smooth, somewhat shiny, continuous, covering areas $\leq 7 \mathrm{~cm}$ diam., under $0.1 \mathrm{~mm}$ thick, pale yellowish grey, not surrounded by prothallus, not inducing gall formation of the host bark.

Ascomata pyriform, c. $0.6-1.0 \mathrm{~mm}$ diam., mostly aggregated $2-5$, mostly immersed in the bark tissue below pseudostromata with a whitish surface different from the thallus, which are distinctly raised above the thallus and mostly linear to irregular in outline and $\leq 4 \mathrm{~mm}$ long and $1 \mathrm{~mm}$ wide, not forming a network. Wall carbonized, $\leq c .80 \mu \mathrm{m}$ thick. Ostioles eccentric, fused, strongly convex, pale brownish, surrounded by a whitish pruinose ring. Hamathecium not inspersed with oil globules. Asci with 8 ascospores. Ascospores hyaline, submuriform, fusiform, 35-40 $\times$ 13-15 $\mu \mathrm{m}$, ends rounded, without thickened median septum, not surrounded by a gelatinous layer.

Chemistry. Thallus UV-, K-; pseudostromata UV+ yellow. TLC: lichexanthone.

Ecology and distribution. On smooth bark of trees in savannah forest. Known only from Guyana.

Discussion. Similar to $A$. eustomuralis, but lichexanthone is present in the whole pseudostroma, not only on the ostiole.

\section{Astrothelium lucidothallinum Aptroot sp. nov.}

MycoBank No.: MB 815223

Astrothelium with the thallus containing lichexanthone; ascomata in pseudostromata without lichexanthone, 
ostioles apical, hamathecium not inspersed, ascospores muriform, 70-90 × 18-20 $\mu \mathrm{m}$.

Type: Guyana, Upper Takutu Distr., c. $30 \mathrm{~km} \mathrm{~S}$ of Aishalton, $\mathrm{N}$ border of Parabara savannah, alt. $300 \mathrm{~m}$, 7 October 1992, H. F. M. Sipman 58038 (B-holotype).

(Fig. 3F)

Thallus corticate, smooth, somewhat shiny, continuous, covering areas $\leq 9 \mathrm{~cm}$ diam., $\leq 0.1 \mathrm{~mm}$ thick, pale yellowish grey, surrounded by a black prothallus line c. $0.1 \mathrm{~mm}$ wide, inducing gall formation of the host bark in the form of bark galls underneath the thallus.

Ascomata almost globose, c. $0 \cdot 8-1 \cdot 2 \mathrm{~mm}$ diam., immersed in pseudostromata, but also in the bark, mostly in groups of 2-8, usually clustered in lines. Pseudostromata whitish, slightly raised and linear. Wall carbonized, $\leq c .150 \mu \mathrm{m}$ thick. Ostioles apical, ochraceous, surrounded by a whitish ring and around this often a thin black ring with exposed ascoma walls. Hamathecium not inspersed. Ascospores 8 per ascus, hyaline, IKI- , densely muriform, $70-90 \times 18-20 \mu \mathrm{m}$, fusiform, without thickened median septum.

Chemistry. Thallus UV+ yellow; pseudostromata in contrast UV-. TLC: lichexanthone.

Ecology and distribution. On smooth bark of trees in savannah forest. Known only from Guyana.

Discussion. Characterized by the thallus containing lichexanthone, contrasting with the pseudostromata which are without lichexanthone; ascospores muriform, 70$90 \times 18-20 \mu \mathrm{m}$.

\section{Astrothelium mediocrassum Aptroot sp. nov.}

MycoBank No.: MB 815224

Astrothelium resembling A. octosporum (Vain.) Aptroot \& Lücking, but without lichexanthone in the thallus or pseudostromata, ascospores muriform, 70-80 $\times$ $22-25 \mu \mathrm{m}$, and median septum strongly thickened.

Type: Guyana, Upper Takutu Distr., c. $45 \mathrm{~km} \mathrm{~S}$ of Aishalton, $3 \mathrm{~km} \mathrm{~S}$ of Kuyuwini Landing, alt. $230 \mathrm{~m}$, 29 October 1992, H. F. M. Sipman 56971 (B-holotype).
(Fig. 4A)

Thallus corticate, smooth, somewhat shiny, continuous, covering areas $\leq 12 \mathrm{~cm}$ diam., $\leq 0.3 \mathrm{~mm}$ thick, pale green, not surrounded by prothallus, not inducing gall formation of the host bark.

Ascomata pyriform, c. $0.6-1.0 \mathrm{~mm}$ diam., mostly aggregated $2-5$, immersed in pseudostromata with a smooth cream surface different from the thallus, which are distinctly raised $c .1 \mathrm{~mm}$ above the thallus and almost constricted at the base. Wall carbonized, $\leq c .80 \mu \mathrm{m}$ thick. Ostioles eccentric, fused, strongly convex, brown. Hamathecium not inspersed with oil globules. Asci with 8 ascospores. Ascospores hyaline, muriform, fusiform, $70-80 \times 22-25 \mu \mathrm{m}$, median septum strongly thickened, ends pointed, not surrounded by a gelatinous layer.

Chemistry. Thallus and pseudostromata UV-, K-. TLC: no secondary substances detected.

Ecology and distribution. On smooth bark of trees in savannah forest. Known only from Guyana.

Discussion. This species resembles A. octosporum, but has no lichexanthone in the thallus or pseudostromata. It has the smallest ascospores of the Astrothelium species, with 8 muriform ascospores per ascus, eccentric and fused ostioles, and a hamathecium without inspersion and without secondary substances.

\section{Astrothelium megatropicum Aptroot sp. nov.}

MycoBank No.: MB 815225

Astrothelium with 3-septate ascospores 100-120 ×33$35 \mu \mathrm{m}$, and hemispherical dark brown pseudostromata.

Type: Guyana, Potaro-Siparuni Region, surroundings of Paramakatoi village, alt. $800 \mathrm{~m}, 23$ February 1996, H. F. M. Sipman 41281 (B-holotype).

(Fig. 4B)

Thallus corticate, smooth, somewhat shiny, continuous, pale ochraceous green, covering areas $\leq 7 \mathrm{~cm}$ diam., c. $0.2 \mathrm{~mm}$ thick, 

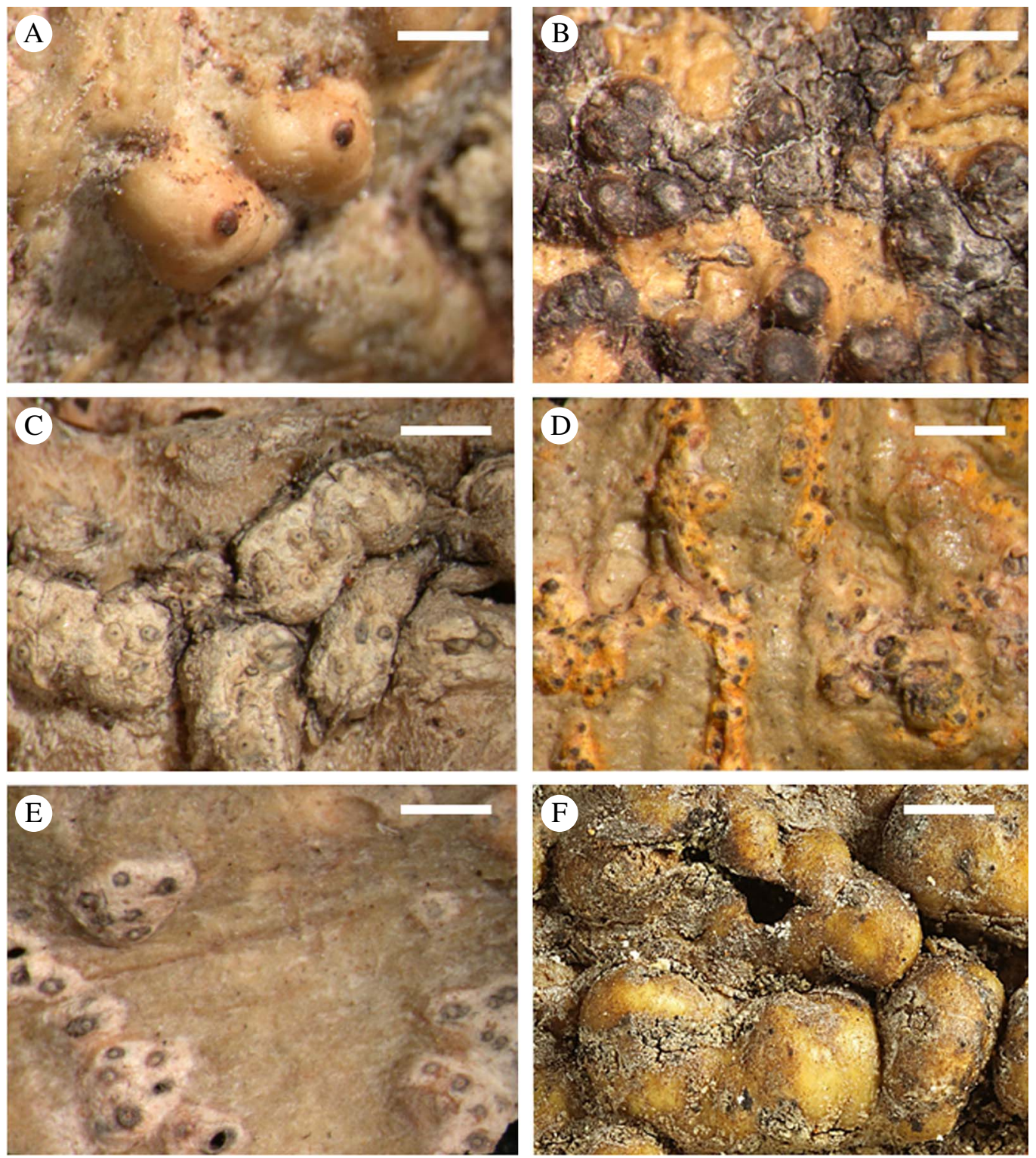

FIG. 4. Habitus of new species of Trypetheliaceae (holotypes). A, Astrothelium mediocrassum; B, A. megatropicum; $\mathrm{C}, A$. megochroleucum; $\mathrm{D}, A$. neoinspersum; $\mathrm{E}, A$. perspersum; $\mathrm{F}, A$. philippinense. Scales: $\mathrm{A}-\mathrm{F}=1 \mathrm{~mm}$. In colour online.

surrounded by a black prothallus line c. $0 \cdot 1 \mathrm{~mm}$ wide, not inducing gall formation of the host bark.

Ascomata globose, $0.6-1.0 \mathrm{~mm}$ diam., mostly single, occasionally 2 aggregated, in hemispherical dark brown pseudostromata without thallus cover. Wall carbonized, $\leq c .100 \mu \mathrm{m}$ thick. Ostioles apical, concave, ochraceous, white pruinose. Hamathecium inspersed with oil globules. Asci with 4-8 ascospores. Ascospores hyaline, 3-septate, ellipsoid, $100-120 \times 33-35 \mu \mathrm{m}$, lumina diamond-shaped, ends rounded, not surrounded by a gelatinous layer. 
Chemistry. Thallus and pseudostromata UV-, $\mathrm{K}-$. TLC: no secondary substances detected.

Ecology and distribution. On smooth bark of trees in savannah forest. Known only from Guyana.

Discussion. This species has by far the longest 3-septate ascospores in the family. The dark brown pseudostromata contrast strongly with the ochraceous thallus and this gives the impression of a species without pseudostromata, such as Nigrovothelium tropicum (Ach.) Lücking et al., hence the name.

\section{Astrothelium megochroleucum Aptroot sp. nov.}

MycoBank No.: MB 815226

Astrothelium with 3-septate ascospores 60-70 $\times 16-18 \mu \mathrm{m}$ and lichexanthone in the thallus and pseudostromata.

Type: El Salvador, Depto. Ahuachapán, Parque Nacional El Imposible, sector L Campana, Cafetal Las Piedrones, on Leucaena trichandra in coffee plantation, alt. $1300 \mathrm{~m}, 10$ November 1998, H. F. M. Sipman, S. Sandoval E F. Welz 44823 (B-holotype).

(Fig. 4C)

Thallus corticate, smooth, somewhat shiny, continuous, covering areas $\leq 4 \mathrm{~cm}$ diam., under $0.1 \mathrm{~mm}$ thick, ochraceous with whitish pruina, surrounded by a black prothallus line $c .0 \cdot 1 \mathrm{~mm}$ wide, inducing gall formation of the host bark, which splits open and forms a callus under the thallus.

Ascomata globose, $0.6-0.9 \mathrm{~mm}$ diam., immersed in groups of c. 2-10 in pseudostromata. Pseudostromata with a surface hardly different from the thallus, c. 0.5$1.0 \mathrm{~mm}$ raised above the thallus, mostly oval in outline, $\leq c .3 \mathrm{~mm}$ diam., with whitish cover, partly brownish inside. Wall black, $\leq 80 \mu \mathrm{m}$ thick. Ostioles apical, not fused, convex, ochraceous to grey. Hamathecium not inspersed with oil globules. Asci with 8 ascospores. Ascospores hyaline, 3-septate, fusiform, $60-70 \times 16-18 \mu \mathrm{m}$, not surrounded by a gelatinous layer.

Chemistry. Thallus and pseudostromata UV+ yellow, K-. TLC: lichexanthone.
Ecology and distribution. On smooth bark of trees in coffee plantation. Known only from El Salvador.

Discussion. This species has the appearance of Astrothelium ochroleucoides Aptroot \& $M$. Cáceres, from which it differs, for example, by the long 3-septate ascospores. It has the longest ascospores among Astrothelium species with 3-septate ascospores and lichexanthone in the thallus and pseudostromata.

\section{Astrothelium neoinspersum Aptroot sp. nov.}

MycoBank No.: MB 815227

Astrothelium similar to $A$. aenascens Aptroot, but with bright yellow pseudostromata.

Type: El Salvador, Santa Ana, Metapan, Parque Nacional Montecristo, 1993, H. f. M. Sipman, F. Berendsohn Eீ L. Ladino 37365 (B-holotype).

(Fig. 4D)

Thallus corticate, smooth, somewhat shiny, continuous, covering areas $\leq 5 \mathrm{~cm}$ diam., c. $0.2 \mathrm{~mm}$ thick, olive-green, not surrounded by a prothallus, not inducing gall formation of the host bark.

Ascomata globose, $0.4-0.7 \mathrm{~mm}$ diam., immersed in groups of $2-10$ in pseudostromata with a surface different from the thallus, and which are distinctly raised above the thallus, irregular to often linear in outline, sides sloping, bright yellow, inside with a cream layer containing bark tissue. Wall dark brown all around, $\leq c$. $70 \mu \mathrm{m}$ thick. Ostioles apical, not fused, flat to convex, black. Hamathecium inspersed with oil globules. Asci with 8 ascospores. Ascospores hyaline, 3-septate, fusiform, $18-23 \times 7-8 \mu \mathrm{m}$, ends rounded, lumina diamond-shaped, surrounded by a $3 \mu \mathrm{m}$ thick gelatinous layer.

Chemistry. Thallus UV-, pseudostromata $\mathrm{UV}+$ red, K+ purple. TLC: an anthraquinone.

Ecology and distribution. On smooth bark of trees in rainforest. Known only from El Salvador.

Discussion. Similar to $A$. aenascens, but with bright yellow pseudostromata. Also similar to 
A. inspersaeneum E. L. Lima et al., which has at least some orange pigmentation on the thallus.

\section{Astrothelium perspersum Aptroot \& Ertz sp. nov.}

MycoBank No.: MB 815228

Astrothelium similar to $A$. scoria (Fée) Aptroot \& Lücking, but with ascospores of 26-38 $\times 7-9 \mu \mathrm{m}$.

Type: Gabon, Nzé, au nord-est de Makokou, entre Massaha et Batouala, 12 April 2006, D. Ertz 9716 (BR-holotype).

(Fig. 4E)

Thallus corticate, smooth, somewhat shiny, continuous, covering areas $\leq 4 \mathrm{~cm}$ diam., $\leq 0 \cdot 1 \mathrm{~mm}$ thick, pale greenish grey, surrounded by a black prothallus line c. $0 \cdot 1 \mathrm{~mm}$ wide, not inducing gall formation of the host bark.

Ascomata almost globose, c. $0.5-0.7 \mathrm{~mm}$ diam., immersed in pseudostromata, but also in the bark, mostly in groups of 2-8, usually clustered in lines. Pseudostromata whitish, slightly raised and linear. Wall carbonized, $\leq$ c. $90 \mu \mathrm{m}$ thick. Ostioles apical, whitish, surrounded by a thin black ring with exposed ascoma walls. Hamathecium inspersed with oil globules. Ascospores 8 per ascus, hyaline, 3-septate, 26-38 $\times 7-9 \mu \mathrm{m}$, lumina diamondshaped.

Chemistry. Thallus and pseudostromata UV-, K-. TLC: no secondary substances detected.

Ecology and distribution. On smooth bark of trees in rainforest. Known only from Gabon.

Discussion. Similar to A. scoria, but with larger ascospores. This is one of the few Trypetheliaceae species described (and known only) from Africa.

\section{Astrothelium philippinense Aptroot \& Schumm sp. nov.}

MycoBank No.: MB 815229

Astrothelium without pseudostromata, ostiole apical, hamathecium inspersed, ascospores muriform, $125-170 \times 30-35 \mu \mathrm{m}, 4$ per ascus.
Type: Philippines, Negros, Negros Oriental, Mt. Talinis, $1100-1600$ m, 19 August 2000, F. Schumm \& S. Schwarz 7532 (B-holotype; hb. Schumm, ABL-isotypes).

(Fig. 4F)

Thallus corticate, smooth, shiny, covering areas $\leq 7 \mathrm{~cm}$ diam., c. $0.2 \mathrm{~mm}$ thick, pale ochraceous green, surrounded by a brown to black prothallus line c. $0.4 \mathrm{~mm}$ wide, inducing gall formation of the host bark in the form of numerous c. 1-2 mm wide hemisperical warts.

Ascomata pyriform, $0.6-0.9 \mathrm{~mm}$ diam., solitary, completely immersed in the bark, below the thallus cortex which, however, can be raised in warts by the bark galls, not in pseudostromata. Wall carbonized all around, $\leq c .80 \mu \mathrm{m}$ thick. Ostioles apical, simple, flat, black, presenting the only part of the ascoma that is visble from above. Hamathecium inspersed with oil globules. Asci with 4 ascospores. Ascospores hyaline, muriform, $125-170 \times 30-35 \mu \mathrm{m}$, ellipsoid, with a distinctly thickened median septum.

Pycnidia not observed with certainty, although some of the many black dots around the ostioles may represent young pycnidia.

Chemistry. Thallus and pseudostromata UV-. TLC: no secondary substances detected.

Ecology and distribution. On smooth bark of trees in rainforest. Known only from the Philippines.

Discussion. Characterized by the combination of the following characters: muriform ascospores, 4 per ascus, without pseudostromata, ostiole apical, hamathecium inspersed.

Additional specimen seen. Philippines: Mindanao: Prov. Cotabato, Mt. Apo, $1250 \mathrm{~m}, 1999$, F. Schumm $\mathcal{E}$ S. Schwarz 5993 (hb. Schumm).

\section{Astrothelium pseudannulare Aptroot \& Etayo sp. nov.}

MycoBank No.: MB 815230

Astrothelium with the appearance of the A. puiggarii (Müll. Arg.) Aptroot \& Lücking-group, but 

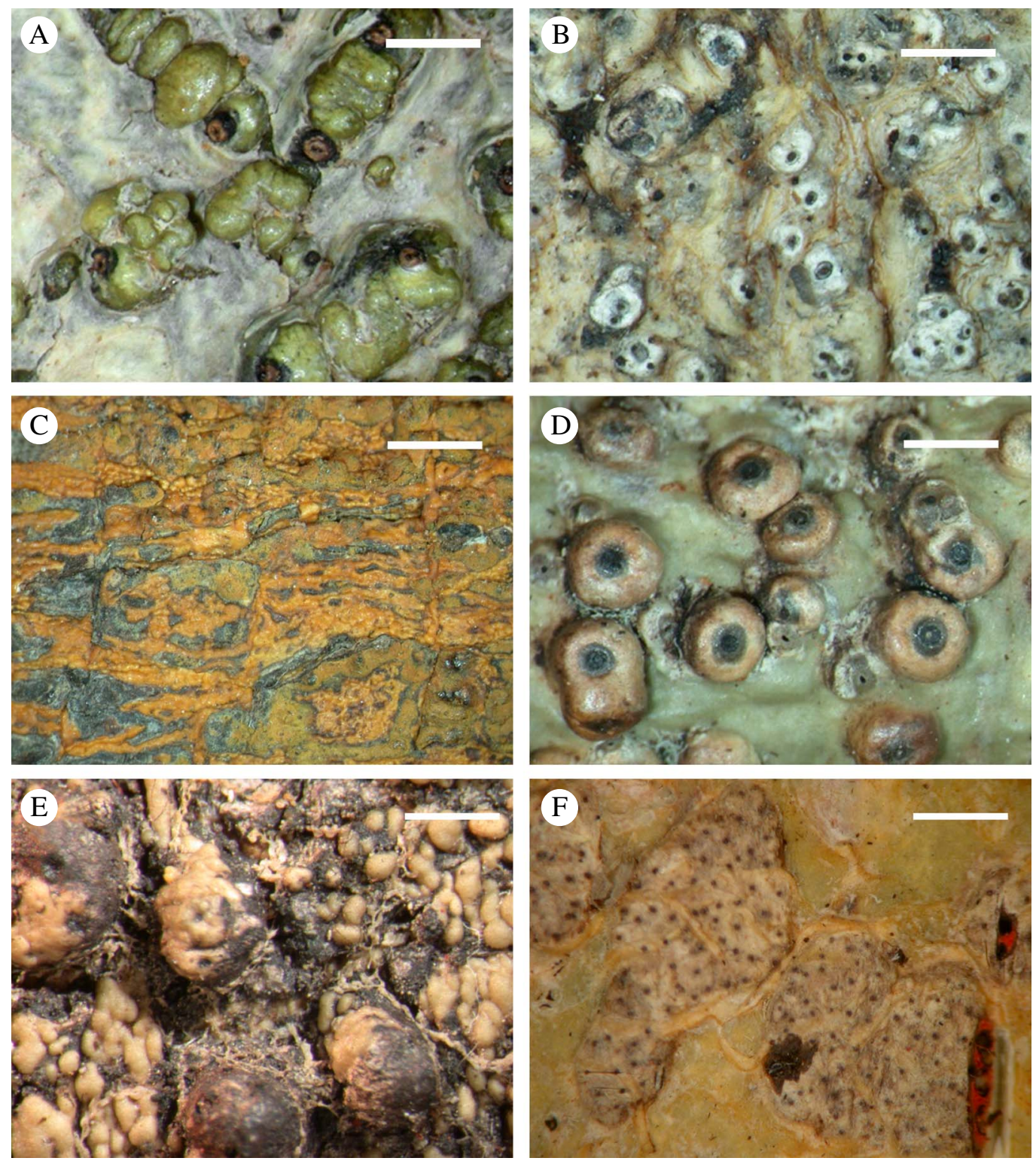

FIG. 5. Habitus of new species of Trypetheliaceae (holotypes). A, Astrothelium pseudannulare; B, A. pseudodissimulum; C, A. pseudoferrugineum; D, A. pseudomegalophthalmum; E, A. rimosum; F, A. sanguineoxanthum. Scales: $\mathrm{A}-\mathrm{F}=1 \mathrm{~mm}$. In colour online.

differing from all other species of it by the 3-septate ascospores $80-88 \times 32-36 \mu \mathrm{m}$, which are 2-4 per ascus.

Type: Ecuador, Loja, Cajanuma, Parque Nacional Podocarpus, nudo de Sabanilla, 3000 m, 4 August 1999, f. Etayo $\mathcal{E}$ Z. Palice 20154 (hb. Etayo-holotype; ABLisotype).
(Fig. 5A)

Thallus consisting of raised, corticate patches, smooth, shiny, covering areas of c. $1.0-3.5 \mathrm{~mm}$ diam., c. $0.2 \mathrm{~mm}$ thick, olivegreen, breaking through the host bark. 
Ascomata globose, $0.7-1.3 \mathrm{~mm}$ diam., single or more often in lines of 2-5, not in pseudostromata. Wall black all around, $\leq c$. $60 \mu \mathrm{m}$ thick. Ostioles apical to often somewhat eccentric, not fused, convex to pointed, brown, surrounded by a black ring c. $0 \cdot 1 \mathrm{~mm}$ wide. Hamathecium not inspersed with oil globules. Asci with 2-4 ascospores. Ascospores hyaline, 3-septate, fusiform, $62-80 \times 20-25 \mu \mathrm{m}$, ends rounded, lumina diamond-shaped, surrounded by an $\leq 12 \mu \mathrm{m}$ thick gelatinous layer.

Pycnidia not observed.

Chemistry. Thallus and medulla UV-, K- . TLC: no secondary substances detected.

Ecology and distribution. On smooth bark of trees in mountain forest. Known only from Ecuador.

Discussion. This is a species with the appearance of the $A$. puiggarii-group, characterized for example by the solitary ascomata with partly eccentric ostioles that are immersed in isolated superficial thallus patches. It would otherwise key out as A. annulare (Mont.) Aptroot \& Lücking because of the large 3-septate ascospores.

\section{Astrothelium pseudodissimulum Aptroot sp. nov.}

MycoBank No.: MB 815231

Astrothelium with $\mathrm{K}+$ red crystals in the ascoma wall and 5-septate ascospores of 25-33 × 9-11 $\mu \mathrm{m}$.

Type: Papua New Guinea, Madang Prov., Brahman Mission, alt. 100 m, 29 October 1995, H. F. M. Sipman 38789 (B-holotype).

(Fig. 5B)

Thallus corticate, rather smooth, continuous, covering areas $\leq 15 \mathrm{~cm}$ diam., c. $0.2 \mathrm{~mm}$ thick, pale yellowish green, not surrounded by a prothallus, partly bullate, apparently inducing irregular gall formation of the host bark.

Ascomata globose, $0.4-0.7 \mathrm{~mm}$ diam., immersed in the thallus, single or in loose groups of $2-9$, not in clear pseudostromata.
Wall black all around, $\leq c .80 \mu \mathrm{m}$ thick, with $\mathrm{K}+$ red crystals. Ostioles apical, not fused, concave, brown. Hamathecium densely inspersed with oil globules. Asci with 8 ascospores. Ascospores hyaline, 5-septate, fusiform, 25-33 $\times 9-11 \mu \mathrm{m}$, ends rounded, lumina diamond-shaped, not surrounded by a gelatinous layer.

Pycnidia not observed.

Chemistry. Thallus and medulla UV-, $\mathrm{K}-$; ascomata wall $\mathrm{K}+$ red. TLC: an anthraquinone.

Ecology and distribution. On smooth bark of trees in rainforest. Known only from Papua New Guinea.

Discussion. This is probably a species of the $A$. annulare (Mont.) Aptroot \& Lückinggroup, characterized for example by the $\mathrm{K}+$ red crystals in the ascoma wall. It keys out near $A$. dissimulum (Makhija \& Patw.) Aptroot \& Lücking because of the 5-septate ascospores.

\section{Astrothelium pseudoferrugineum Aptroot sp. nov.}

MycoBank No.: MB 815232

Astrothelium of the A. conicum Eschw.-group with an orange thallus and pseudostroma pruina, differing from A. ferrugineum (Müll. Arg.) Aptroot \& Lücking by the 28-31 $\times 9-11 \mu \mathrm{m}$ ascospores and the glossier thallus.

Type: Indonesia, Java, Djombang, October 1937, P. Groenhart 5739 (L-holotype; ABL-isotype).

\section{(Fig. 5C)}

Thallus corticate, smooth, somewhat shiny to glossy, continuous, covering areas $\leq 3 \mathrm{~cm}$ diam., c. $0 \cdot 1 \mathrm{~mm}$ thick, bright orange, not surrounded by a prothallus.

Ascomata pyriform, $0.2-0.3 \mathrm{~mm}$ wide, $0.3-$ $0.5 \mathrm{~mm}$ high, immersed in pseudostromata. Pseudostromata conical, raised above the thallus, with orange pruina. Wall black all around, $\leq$ c. $90 \mu \mathrm{m}$ thick. Ostioles eccentric, 2-5 fused, convex to pointed, black. Hamathecium not inspersed with oil globules. Asci with 8 ascospores. Ascospores hyaline, 
3-septate, fusiform, 28-31 ×9-11 $\mu \mathrm{m}$, ends somewhat pointed, lumina diamond-shaped, not surrounded by a gelatinous layer.

Pycnidia not observed.

Chemistry. Thallus UV-, K-; pseudostromata UV+ red, K+ purple. TLC: an orange anthraquinone, possibly parietin.

Ecology and distribution. On smooth bark of trees in disturbed rainforest. Known only from Indonesia.

Discussion. This is a species of the A. conicumgroup, characterized for example by the conical pseudostromata with anthraquinone. It differs from all species except $A$. ferrugineum (Müll. Arg.) Aptroot \& Lücking by the orange thallus, and from this species by the larger ascospores and glossier thallus.

\section{Astrothelium pseudomegalophthalmum Aptroot sp. nov.}

MycoBank No.: MB 815233

Astrothelium similar to A. megaspermum (Mont.) Aptroot \& Lücking, but differing by the 7 -septate ascospores of 152-166 × 32-37 $\mu \mathrm{m}$.

Type: Colombia, Amazonas, Araracuara, opposite Isla Morrocoy, alt. $300 \mathrm{~m}, 3$ November 1988, H. F. M. Sipman E F. van Duivenvoorden 28501 (B-holotype).

(Fig. 5D)

Thallus corticate, smooth, somewhat shiny, continuous, covering areas $\leq 7 \mathrm{~cm}$ diam., c. $0.1 \mathrm{~mm}$ thick, pale olive-green, surrounded by a thin brown prothallus, not inducing irregular gall formation of the host bark.

Ascomata globose, $0.7-1.1 \mathrm{~mm}$ diam., superficial, completely covered by thallus, not in pseudostromata; warts hemispherical, c. $0.9-1.4 \mathrm{~mm}$ diam. and $0.6-1.1 \mathrm{~mm}$ high. Wall black all around, $\leq c .70 \mu \mathrm{m}$ thick. Ostioles apical, not fused, concave, black, surrounded by a brown ring $c .0 .2 \mathrm{~mm}$ wide. Hamathecium densely inspersed with oil globules. Asci with 8 ascospores. Ascospores hyaline, 7-septate, fusiform, 152-166× 32-37 $\mu \mathrm{m}$, ends rounded, lumina diamondshaped, not surrounded by a gelatinous layer.
Pycnidia not observed.

Chemistry. Thallus and medulla UV-, K-. TLC: no secondary substances detected.

Ecology and distribution. On smooth bark of trees in savannah forest. Known only from Colombia.

Discussion. This species has the appearance of $A$. megaspermum, characterized for example by the superficial single ascomata in hemispherical warts, but it differs by the only transversely septate ascospores. It keyed out near A. megalophthalmum (Müll. Arg.) Aptroot \& Lücking because of the large 7 -septate ascospores.

\section{Astrothelium rimosum Aptroot sp. nov.}

MycoBank No.: MB 815234

Astrothelium with 7-11-septate ascospores, 110-150× 30-37 $\mu \mathrm{m}$, and a rimose thallus with yellow medulla.

Type: Guyana, Potaro-Siparuni Region, Kaieteur Falls National Park, around airstrip, sclerophyllous forest, alt. $400 \mathrm{~m}, 13-20$ February 1996, H. F. $M$. Sipman 40391 (B-holotype).

(Fig. 5E)

Thallus olive-green to yellowish green, strongly rimose, partly with almost globose lobules, with a thick hyaline cortex, medulla pale citrine yellow, not surrounded by a prothallus, not inducing gall formation of the bark.

Ascomata globose, $0.7-1.1 \mathrm{~mm}$ diam., superficial, solitary or a few fused sideways, brown, often with constricted base, at the sides partly covered by thallus, not in pseudostromata. Wall carbonized, $\leq c .90 \mu \mathrm{m}$ thick. Ostioles apical to eccentric, black, convex. Hamathecium inspersed with oil globules. Asci with 8 ascospores. Ascospores hyaline, 7-11-septate, $110-150 \times 30-37 \mu \mathrm{m}$, lumina diamond-shaped.

Chemistry. Thallus UV-, K+ red, especially the medulla; with anthraquinone.

Ecology and distribution. On smooth bark of trees in rainforest. Known from Colombia and Guyana. 
Discussion. Characterized by the 7-11septate ascospores of $110-150 \times 30-37 \mu \mathrm{m}$ and the rimose thallus with yellow medulla. It is similar to A. luridum (Zahlbr.) Aptroot \& Lücking, which also has a yellow medulla and 7-11-septate ascospores, but which has much shorter ascospores of, at most, $88 \mu \mathrm{m}$.

Additional material seen. Colombia: Depto. Valle del Cauca: Buenaventura, alt. $230 \mathrm{~m}$, M. van Rooden, B. F. H. ter Welle \& B. Topper 571 (B).

\section{Astrothelium sanguineoxanthum Aptroot sp. nov.}

MycoBank No.: MB 815235

Astrothelium with the thallus containing lichexanthone and pseudostromata with numerous immersed round ascomata, the whole inside of which is full of red, $\mathrm{K}+$ green pigment.

Type: Brazil, Matto Grosso, Santa Anna da Chapada, 21 March 1894, G. O. A. Malme 2484C (S-holotype).

\section{(Fig. 5F)}

Thallus green to greyish, smooth.

Pseudostromata whitish, rather flat, rounded to irregular in shape or elongated, with rather steep sides, generally with numerous immersed round ascomata with complete black wall, $\leq 5 \mathrm{~mm}$ long and $2 \mathrm{~mm}$ wide, the whole inside full of red, $\mathrm{K}+$ green pigment. Ostioles apical, black, flush. Hamathecium not inspersed, filaments profusely anastomosing. Ascospores 8 per ascus, muriform, 59-86 × 15-20 $\mu \mathrm{m}$, IKI+ violet, without strongly thickened median septum.

Chemistry. Thallus UV+ yellow, K-, pseudostroma exterior UV+ yellow, inside pink, reacting $\mathrm{K}+$ green; with lichexanthone and isohypocrellin.

Ecology and distribution. On smooth bark of trees in rainforest. Known only from Brazil.

Discussion. The only Astrothelium with the thallus containing lichexanthone and pseudostromata with numerous immersed round ascomata, the whole inside of which is full of the red, $\mathrm{K}+$ green pigment isohypocrellin.
Additional specimen seen. Brazil: same locality, 1894, G. O. A. Malme $2530 \mathrm{D}$ p.p. (S).

\section{Astrothelium septemseptatum Aptroot sp. nov.}

MycoBank No.: MB 815236

Astrothelium with the thallus and pseudostromata UV+ yellow and 7-9-septate ascospores of 50-55 × 12-17 $\mu \mathrm{m}$.

Type: Guyana, Upper Takutu Distr., c. $45 \mathrm{~km} \mathrm{~S}$ of Aishalton, $3 \mathrm{~km} \mathrm{~S}$ of Kuyuwini Landing, alt. $230 \mathrm{~m}$, 29 October 1992, H. F. M. Sipman 56970 (B-holotype).

(Fig. 6A)

Thallus corticate, smooth, somewhat shiny, continuous, covering areas $\leq 9 \mathrm{~cm}$ diam., under $0.1 \mathrm{~mm}$ thick, pale yellowish grey, surrounded by a $\leq 0.5 \mathrm{~mm}$ wide black prothallus, not inducing gall formation of the host bark.

Ascomata pyriform, c. $0.6-1.0 \mathrm{~mm}$ diam., mostly aggregated $2-5$, mostly immersed in the bark tissue below pseudostromata with a whitish surface different from the thallus, which are distinctly raised above the thallus and mostly linear to irregular in outline, and $\leq 4 \mathrm{~mm}$ long and $1 \mathrm{~mm}$ wide. Wall carbonized, $\leq c .80 \mu \mathrm{m}$ thick. Ostioles eccentric, fused, strongly convex, pale brownish, surrounded by a whitish pruinose ring. Hamathecium not inspersed with oil globules. Asci with 8 ascospores. Ascospores hyaline, fusiform, 7-9-septate, $50-55 \times 12-17 \mu \mathrm{m}$, ends rounded, not surrounded by a gelatinous layer.

Chemistry. Thallus (mostly) and pseudostromata (everywhere) UV+ yellow, $\mathrm{K}-$. TLC: lichexanthone.

Ecology and distribution. On smooth bark of trees in savannah and rainforest. Known from Guyana and Venezuela.

Discussion. The only Astrothelium with a UV+ yellow thallus and pseudostromata, and 7-9-septate ascospores.

Additional specimens seen. Venezuela: Amazonas: Alto Orinoco, Surumoni, 1998, f. Hafellner $\mathcal{E}$ H. Komposch 3264, 3290 \& 3342 (GZU). 

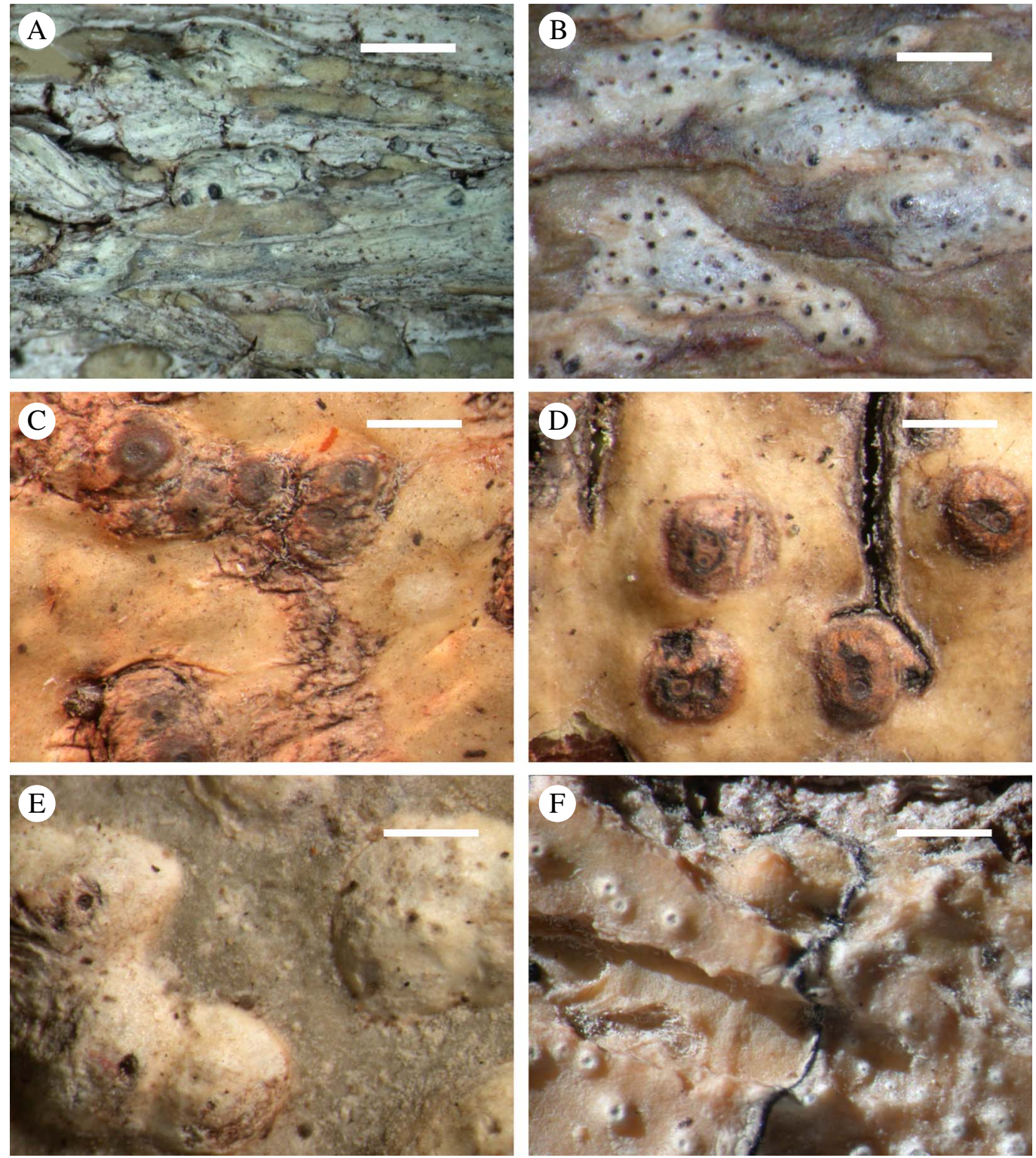

Fig. 6. Habitus of new species of Trypetheliaceae (holotypes). A, Astrothelium septemseptatum; B, A. sexloculatum; C, $A$. sipmanii; D, A. trypethelioides; E, A. ultralucens; F, A. vulcanum. Scales: A-F $=1 \mathrm{~mm}$. In colour online.

\section{Astrothelium sexloculatum Aptroot sp. nov.}

MycoBank No.: MB 815237

Astrothelium with 5-septate ascospores of 25-27 $\times 7-11 \mu \mathrm{m}$ and lichexanthone in the thallus and pseudostromata.

Type: Guyana, Upper Takutu Distr., Rupununi Savannah, Dadadanawa ranch, near headquarters, alt. $120 \mathrm{~m}, 20$ September-16 November $1992, H$. F. M. Sipman 57381 (B-holotype).

(Fig. 6B)

Thallus corticate, smooth, somewhat shiny, continuous, covering areas $\leq 9 \mathrm{~cm}$ diam., under $0.1 \mathrm{~mm}$ thick, pale yellowish 
grey, surrounded by a $\leq 1 \mathrm{~mm}$ wide black prothallus, not inducing gall formation of the host bark.

Ascomata pyriform, c. $0.6-1.0 \mathrm{~mm}$ diam., mostly aggregated $2-5$, mostly immersed in the bark tissue below pseudostromata with a whitish surface different from the thallus, which are distinctly raised above the thallus and mostly linear to irregular in outline, $\leq 4 \mathrm{~mm}$ long and $1 \mathrm{~mm}$ wide, often forming a network. Wall carbonized, $\leq c .80 \mu \mathrm{m}$ thick. Ostioles eccentric, fused, strongly convex, pale brownish, surrounded by a whitish pruinose ring. Hamathecium not inspersed with oil globules. Asci with 8 ascospores. Ascospores hyaline, fusiform, (3-)5-septate, 25-27 $\times 7-11 \mu \mathrm{m}$, ends rounded, not surrounded by a gelatinous layer.

Chemistry. Thallus and pseudostromata UV+ yellow (pseudostromata stronger than thallus), K-. TLC: lichexanthone.

Ecology and distribution. On smooth bark of trees in savannah forest. Known from Guyana and Papua New Guinea.

Discussion. Astrothelium diplocarpoides Müll. Arg. is the only other species with 5-septate ascospores and lichexanthone in the thallus and pseudostromata; however, it has much larger ascospores of at least $80 \mu \mathrm{m}$.

Additional material seen. Guyana: Upper Takutu Distr.: Rupununi Savannah, Kusad Mountain, alt. $450 \mathrm{~m}$, 1992, H. F. M. Sipman 57820 (B).-Papua New Guinea: Central Prov.: Varirata National Park, 1995, H. F. M. Sipman 38638 (B).

\section{Astrothelium sipmanii Aptroot sp. nov.}

\section{MycoBank No.: MB 815238}

Astrothelium with simple ascomata with 5 -septate ascospores $100-150 \times 35-40 \mu \mathrm{m}$ and an inspersed hamathecium.

Type: Guyana, Upper Takutu Distr., c. $35 \mathrm{~km} \mathrm{~S}$ of Aishalton. $4 \mathrm{~km} \mathrm{~N}$ of Kuyuwini Landing, along track to Karaudanawa, alt. $250 \mathrm{~m}, 31$ October 1992, H. F. M. Sipman 57080 (B-holotype).

(Fig. 6C)

Thallus corticate, smooth to somewhat bullate, shiny, covering areas $\leq 4 \mathrm{~cm}$ diam., c. $0.2 \mathrm{~mm}$ thick, pale ochraceous green, surrounded by a $\leq 1 \mathrm{~mm}$ wide black prothallus, inducing dispersed hemispherical galls of the host bark.

Ascomata pyriform, 0.7-1.2 mm diam., solitary or 2-4 together, emergent from decorticated flat areas that are almost flush with the thallus but that can be seen as ochraceous white pseudostromata, emergent parts brown. Wall carbonized all around, $\leq c .80 \mu \mathrm{m}$ thick. Ostioles apical, simple, concave, black. Hamathecium inspersed with oil globules. Asci with 8 ascospores. Ascospores hyaline, 5-septate, $100-150 \times 35-40 \mu \mathrm{m}$, ellipsoid.

Pycnidia not observed with certainty, although some of the many black dots around the ostioles may represent young pycnidia.

Chemistry. Thallus and pseudostromata UV-, K-. TLC: no secondary substances detected.

Ecology and distribution. On smooth bark of trees in savannah forest. Known only from Guyana.

Discussion. Characterized by the simple ascomata with 5-septate ascospores of more than $100 \mu \mathrm{m}$ and the inspersed hamathecium. Astrothelium curvisporum Aptroot \& M. Cáceres shares these characters but has distinctly curved ascospores; $A$. pustulatum (Vain.) Aptroot \& Lücking has generally more septa and longer ascospores of at least $180 \mu \mathrm{m}$.

\section{Astrothelium trypethelioides Aptroot sp. nov.}

MycoBank No.: MB 815239

Astrothelium with fused ostioles, an inspersed hamathecium and 7-9-septate ascospores of 49-52 × 13-16 $\mu \mathrm{m}$.

Type: Venezuela, Bolivar, Cerro Guaiquinima, along Rio Carapo, alt. $800 \mathrm{~m}, 11$ February 1990, H. F. M. Sipman 26976 (B-holotype).

(Fig. 6D)

Thallus corticate, smooth, somewhat shiny, continuous, covering areas $\leq$ at least $9 \mathrm{~cm}$ diam., under $0.1 \mathrm{~mm}$ thick, pale 
yellowish grey, prothallus not observed, not inducing gall formation of the host bark.

Ascomata pyriform, c. $0.4-0.6 \mathrm{~mm}$ diam., mostly aggregated $2-9$, mostly immersed in the bark tissue below pseudostromata with pale brownish surfaces different from the thallus, which are distinctly raised above the thallus and mostly ellipsoid in outline, $\leq 2 \mathrm{~mm}$ long and $1 \mathrm{~mm}$ wide. Wall brown, $\leq c$. $60 \mu \mathrm{m}$ thick. Ostioles eccentric, fused, convex, black. Hamathecium inspersed with oil globules. Asci with 8 ascospores. Ascospores hyaline, fusiform, 7-9-septate, 49-52 $\times 13-16 \mu \mathrm{m}$, ends pointed, not surrounded by a gelatinous layer.

Chemistry. Thallus and pseudostromata $\mathrm{K}-$, UV-. TLC: no secondary substances detected.

Ecology and distribution. On smooth bark of trees in rainforest. Known only from Venezuela.

Discussion. This species is characterized by the combination of fused ostioles, an inspersed hamathecium and 7-9-septate ascospores.

\section{Astrothelium ultralucens Aptroot sp. nov.}

MycoBank No.: MB 815240

Astrothelium with the thallus and pseudostromata containing lichexanthone, fused ostioles and 3-septate ascospores over $105-130 \times 35-42 \mu \mathrm{m}$.

Type: Venezuela, Bolivar, Cerro Guaiquinima, along Rio Carapo, alt. $800 \mathrm{~m}, 12$ February 1990, H. F. M. Sipman 27057 (B-holotype).

(Fig. 6E)

Thallus corticate, smooth, somewhat shiny, continuous, covering areas $\leq$ at least $7 \mathrm{~cm}$ diam., under $0.1 \mathrm{~mm}$ thick, pale greenish grey, without prothallus, not inducing gall formation of the host bark.

Ascomata pyriform, c. $0.7-1.2 \mathrm{~mm}$ diam., mostly aggregated $2-7$, mostly immersed in the bark tissue below pseudostromata with a whitish surface different from the thallus, which are distinctly raised above the thallus and mostly ellipsoid to irregular in outline, $\leq 4 \mathrm{~mm}$ long and $3 \mathrm{~mm}$ wide. Wall carbonized, $\leq c .180 \mu \mathrm{m}$ thick. Ostioles eccentric, fused, flat, ochraceous. Hamathecium not inspersed with oil globules. Asci with 8 ascospores. Ascospores hyaline, fusiform, 3-septate, 105-130 × 35-42 $\mu \mathrm{m}$, ends rounded, surrounded by a gelatinous layer c. $3 \mu \mathrm{m}$ thick.

Chemistry. Thallus UV+ yellow (but much duller than the pseudostromata and therefore easily overlooked), $\mathrm{K}-$; pseudostromata $\mathrm{UV}+$ yellow, K-. TLC: lichexanthone.

Ecology and distribution. On smooth bark of trees in rainforest. Known only from Venezuela.

Discussion. This species is characterized by the combination of fused ostioles, lichexanthone in the thallus and pseudostromata, and 3-septate ascospores of over $100 \mu \mathrm{m}$.

\section{Astrothelium vulcanum Aptroot sp. nov.}

\section{MycoBank No.: MB 815241}

Astrothelium of the A. nitidiusculum (Nyl.) Aptroot \& Lücking-group, with simple ascomata, an inspersed hamathecium and containing lichexanthone.

Type: Guyana, Rupununi District, Kuyuwini Landing, alt. $200 \mathrm{~m}, 5$ February 1991, M. F. Fansen-facobs, B. F. ter Welle, D. Gopaul \& V. Fames 2400 (L-holotype; ABL - isotype).

(Fig. 6F)

Thallus corticate, smooth, somewhat shiny, continuous, covering areas $\leq 25 \mathrm{~cm}$ diam., c. $0.1 \mathrm{~mm}$ thick, pale ochraceous, surrounded by a thin black prothallus line, not inducing gall formation of the host bark.

Ascomata globose, 0.3-0.6 mm diam., single, immersed in the thallus and partly in the bark, tops slightly protruding. Wall black or dark brown all around, $\leq c .50 \mu \mathrm{m}$ thick. Ostioles apical, not fused, concave, whitish, surrounded by a cream-coloured ring c. $0 \cdot 1 \mathrm{~mm}$ wide. Hamathecium densely inspersed with oil globules. Asci with 8 ascospores. Ascospores hyaline, 3-septate, 
fusiform, 20-25 × 6.5-7.5 $\mu \mathrm{m}$, ends rounded, lumina diamond-shaped, not surrounded by a gelatinous layer.

Pycnidia not observed.

Chemistry. Thallus UV+ yellow, K-. TLC: lichexanthone.

Ecology and distribution. On smooth bark of trees in savannah forest. Known only from Guyana.

Discussion. This is a species of the A. nitidiusculum-group, which is split up again. It differs from $A$. nitidiusculum $\mathrm{s}$. str. by the inspersed hamathecium and the presence of lichexanthone.

\section{Astrothelium zebrinum Aptroot sp. nov.}

MycoBank No.: MB 815242

Astrothelium with fused ostioles and 7-septate ascospores 60-70 $\mu \mathrm{m}$ long, without lichexanthone, anthraquinones or inspersion.

Type: Guyana, Potaro-Siparuni Region, Kaieteur Falls National Park, around airstrip, sclerophyllous forest, 20 February 1996, H. F. M. Sipman 40580 (B-holotype).

(Fig. 7A)

Thallus corticate, smooth, somewhat shiny, continuous, covering areas $\leq 9 \mathrm{~cm}$ diam., under $0.1 \mathrm{~mm}$ thick, pale yellowish grey, not surrounded by prothallus, not inducing gall formation of the host bark.

Ascomata pyriform, c. $0 \cdot 6-1 \cdot 2 \mathrm{~mm}$ diam., mostly aggregated $2-5$, mostly immersed in the bark tissue below pseudostromata with a whitish surface different from the thallus, which are slightly raised above the thallus and mostly linear to irregular in outline, and $\leq 1 \mathrm{~cm}$ long and $4 \mathrm{~mm}$ wide, not forming a network. Wall carbonized, $\leq c$. $80 \mu \mathrm{m}$ thick. Ostioles eccentric, fused, strongly convex, pale brownish, surrounded by a thick whitish pruinose ring. Hamathecium not inspersed with oil globules. Asci with 8 ascospores. Ascospores hyaline, fusiform, 7-septate, $60-70 \times 14-28 \mu \mathrm{m}$, ends pointed, not surrounded by a gelatinous layer.
Chemistry. Thallus and pseudostromata UV-, K-. TLC: no secondary substances detected.

Ecology and distribution. On smooth bark of trees in rainforest. Known only from Guyana.

Discussion. Characterized by the combination of fused ostioles, absence of inspersion and secondary substances, and 7-septate ascospores $60-70 \mu \mathrm{m}$ long.

\section{Polymeridium rhodopruinosum Aptroot \& Mercado Diaz sp. nov.}

\begin{abstract}
MycoBank No.: MB 815243
Polymeridium with red pruina on the ascomata and 3-septate ascospores 17-19 × 3.5-5.0 $\mu \mathrm{m}$.

Type: Puerto Rico, Maricao, Bosque estatal de Maricao, Vereda Los Viveros, alt. c. $850 \mathrm{~m}$, on tree bark in disturbed primary sclerophyllous forest, 18 February 2014, A. Aptroot 72208 (UPR-holotype; ABL, F-isotypes).
\end{abstract}

\section{(Fig. 7B)}

\section{Thallus ecorticate, white.}

Ascomata $0.1-0.3 \mathrm{~mm}$ diam., solitary, erumpent, black, glossy, partly with dark red pruina. Ostioles apical, white. Hamathecium not inspersed with oil droplets. Ascospores 8 per ascus, IKI - , 3-septate, 17-19 19.5 $5.0 \mu \mathrm{m}$, not ornamented, wall not thickened, surrounded by a $1 \mu \mathrm{m}$ thick gelatinous sheath.

Chemistry. Thallus UV-, ascoma pruina UV+ dark blood red (almost black). TLC: an anthraquinone.

Ecology and distribution. On smooth bark of trees in disturbed primary sclerophyllous forest. Known only from Puerto Rico.

Discussion. This is the only Polymeridium with red pruina and the only species in the family with a white thallus and black ascomata with red pruina.

\section{Pseudopyrenula americana Aptroot sp. nov.}

MycoBank No.: MB 815244

Pseudopyrenula with 3-septate ascospores of $26-32 \times$ $7-10 \mu \mathrm{m}$, without inspersion and without lichexanthone. 

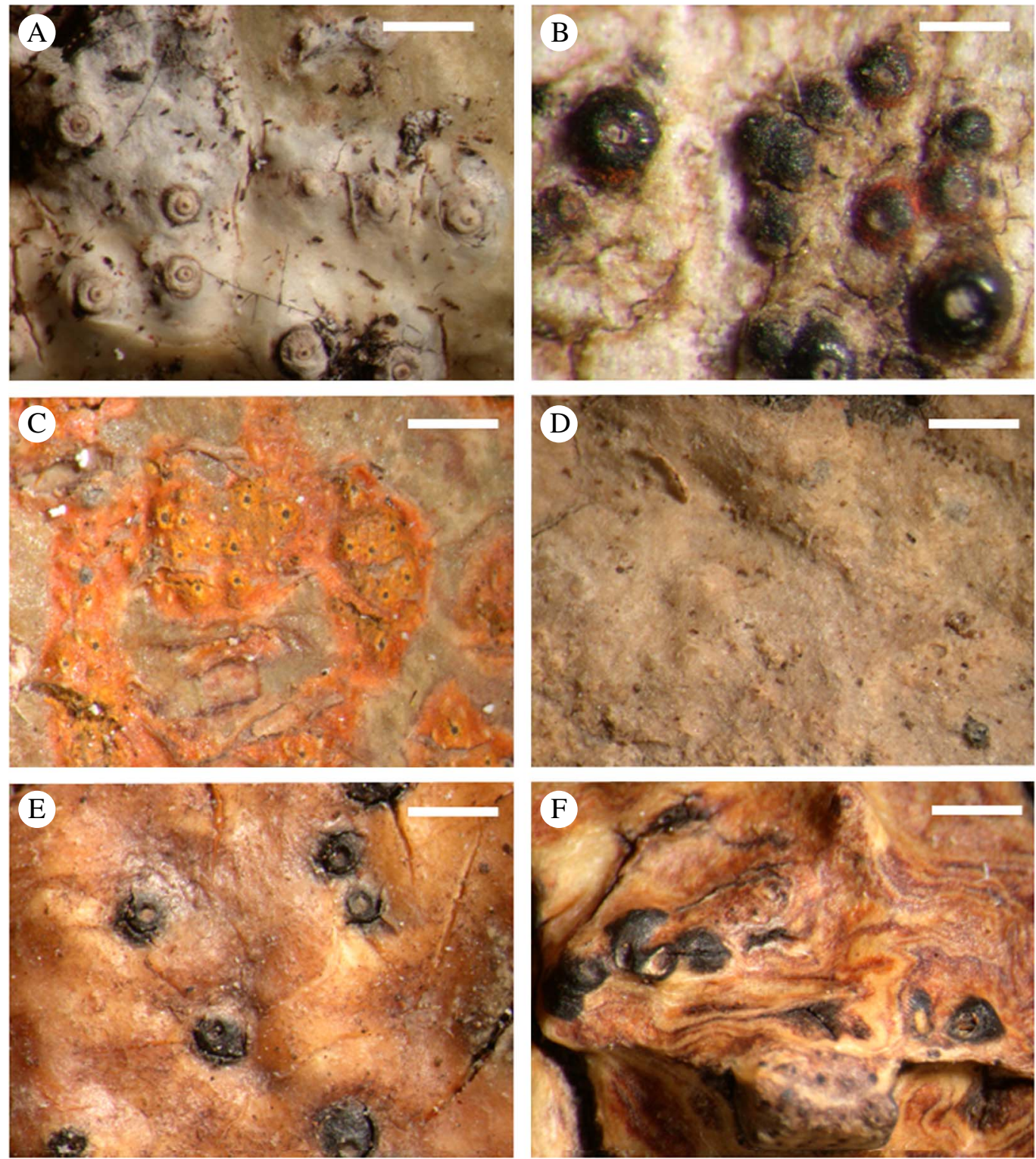

FIG. 7. Habitus of new species of Trypetheliaceae (holotypes). A, Astrothelium zebrinum; B, Polymeridium rhodopruinosum; C, Trypethelium infraeluteriae; D, Viridothelium inspersum; E, V. kinabaluense; F, V. solomonense. Scales: $\mathrm{A}, \mathrm{C}-\mathrm{F}=1 \mathrm{~mm} ; \mathrm{B}=0.2 \mathrm{~mm}$. In colour online.

Type: Guyana, Upper Mazaruni Distr., $\mathrm{N}$ slope of Mount Roraima, alt. c. $700 \mathrm{~m}$, in c. $25 \mathrm{~m}$ tall virgin mossy forest, $25 \mathrm{~m}$ high in canopy, 12-19 February 1985, H. F. M. Sipman E A. Aptroot 18699 (B-holotype).
Thallus ecorticate, whitish.

Ascomata solitary or occasionally a few fused sideways, hemispherical, black, 0.3$0.5 \mathrm{~mm}$ diam. Ostioles apical, whitish to 
black. Hamathecium not inspersed, hyaline. Ascospores 8 per ascus, IKI-, 3-septate, 26-32 $\times 7-10 \mu \mathrm{m}$, not ornamented, lumina diamond-shaped.

Chemistry. Thallus UV-. TLC: no secondary substances detected.

Ecology and distribution. On smooth bark of trees in rainforest. Known only from Guyana.

Discussion. This is a mostly negatively characterized species of the Pseudopyrenula diluta (Fée) Müll. Arg.-group (the medium sizespored 3-septate Pseudopyrenula species), without inspersion and without lichexanthone.

Additional specimen seen. Guyana: Upper Mazaruni Distr.: Mount Latipu, c. $8 \mathrm{~km} \mathrm{~N}$ of Kamarang, alt. c. $1000 \mathrm{~m}$, in scrub on summit plateau, 1985, H. F. M. Sipman E A. Aptroot 19117 (B).

\section{Pseudopyrenula guianensis Aptroot sp. nov.}

MycoBank No.: MB 815245

Pseudopyrenula with a hyaline hamathecium with inspersion, a thallus with lichexanthone and 3-septate ascospores $21-25 \times 6-9 \mu \mathrm{m}$.

Type: French Guiana, Saül, 1986, D. Montfoort $\mathcal{E}$ R. Ek 385 (B-holotype; L-isotype).

Thallus ecorticate, whitish.

Ascomata solitary, hemispherical, black, 0.3-0.5 mm diam. Ostioles apical. Hamathecium hyaline, inspersed with oil droplets. Ascospores 3-septate, 21-25 × 6-9 $\mu \mathrm{m}$, not ornamented, lumina diamond-shaped.

Chemistry. Thallus UV+ yellow. TLC: lichexanthone.

Ecology and distribution. On smooth bark of trees in rainforest. Known from Surinam and French Guiana.

Discussion. This is a species of the Pseudopyrenula subgregaria Müll. Arg.-group (the smaller-spored 3-septate Pseudopyrenula species) characterized by a hyaline hamathecium with inspersion and a thallus with lichexanthone.

Additional specimen seen. Surinam: Brokopondo area, R. Zielman 1307 (ABL, L).

\section{Pseudopyrenula hexamera Aptroot sp. nov.}

MycoBank No.: MB 815246

Pseudopyrenula with 5-septate ascospores 16-21× 6-7 $\mu \mathrm{m}$, lumina clearly diamond-shaped.

Type: Venezuela, Est. Amazonas, Alto Orinoco, $15 \mathrm{~km}$ W of Esmeralda, W bank of Surumoni, on Qualea sp., alt. $110 \mathrm{~m}, 10$ February 1997, F. Hafellner $\mathcal{E}$ H. Komposch 178-5-48 (GZU-holotype).

Thallus ecorticate, whitish.

Ascomata solitary or occasionally a few sideways, hemispherical, black, c. $0.2 \mathrm{~mm}$ diam. Ostioles apical, black. Hamathecium not inspersed, hyaline. Ascospores 5-septate, 16-21× 6-7 $\mu \mathrm{m}$, not ornamented, with a $1 \mu \mathrm{m}$ thick gelatinous sheath, lumina diamond-shaped.

Chemistry. Thallus UV-. TLC: no secondary substances detected.

Ecology and distribution. On smooth bark of trees in rainforest. Known only from Venezuela.

Discussion. This is the only Pseudopyrenula with 5-septate ascospores. It resembles Polymeridium quinqueseptatum (Nyl.) R. C. Harris except for the thickened ascospore walls leaving diamond-shaped lumina. The specimen was already named in the herbarium and in an accompanying unpublished manuscript which was kindly made available to me by Harald Komposch.

\section{Pseudopyrenula thallina Lücking \& Aptroot sp. nov.}

MycoBank No.: MB 815247

Pseudopyrenula with a greenish corticate thallus and 3-septate ascospores, $21-25 \times 6-9 \mu \mathrm{m}$.

Type: Costa Rica, Guanacaste, Hacienda Granadilla, 500-600 m, 10 February 1930, C. W. Dodge $\mathcal{E}$ E. Thomas 6787 (FH-DODGE-holotype). 
Thallus yellow-green, corticate, somewhat shiny, without pseudocyphellae, without prothallus.

Ascomata solitary. Ostioles apical. Hamathecium hyaline, inspersed with oil droplets. Ascospores 3-septate, 21-25 × 6-9 $\mu \mathrm{m}$.

Chemistry. Thallus UV-. TLC: no secondary substances detected.

Ecology and distribution. On smooth bark of trees in rainforest. Known only from Costa Rica.

Discussion. This is the only Pseudopyrenula with a distinct thallus. It is similar to $P$. subnudata Müll. Arg. These specimens have already been commented upon in Aptroot et al. (2008: 86), but not formally described before.

Additional specimen seen. Costa Rica: San José, Guayabillos, C. W. Dodge E E. Thomas 5319 (FH-DODGE).

\section{Trypethelium infraeluteriae Aptroot \& Gueidan sp. nov.}

MycoBank No.: MB 815248

Trypethelium similar to T. subeluteriae Makhija \& Patw., but with lower pseudostromata and ascospores 7-9septate, $37-42 \times 9-11 \mu \mathrm{m}$.

Type: Vietnam, Western Highlands, Dong Nai Province, Cát Tiên National Park, $10 \mathrm{~km}$ south-west of the accommodation area, in a tree plantation near a gate leading to the minority village, 16 February 2012, C. Gueidan 3052 (BM-holotype; ABL, VNMNisotypes).

(Fig. 7C)

Thallus corticate, smooth, somewhat shiny, continuous, covering areas $\leq$ at least $5 \mathrm{~cm}$ diam., c. $0.1 \mathrm{~mm}$ thick, olive-greenish grey, prothallus not observed, not inducing gall formation of the host bark.

Ascomata globose, $0.3-0.5 \mathrm{~mm}$ diam., immersed in groups of $6-15$ in pseudostromata with surfaces different from the thallus, which are slightly raised above the thallus, irregular to often linear in outline, $\leq 8 \mathrm{~mm}$ long and $2 \mathrm{~mm}$ wide, occasionally forming a net, orange. Wall dark brown all around, $\leq c .50 \mu \mathrm{m}$ thick. Ostioles apical, not fused, flat to concave, grey. Hamathecium not inspersed with oil globules. Asci with 8 ascospores. Ascospores hyaline, fusiform, 7-9-septate, 37-42 ×9-11 $\mu \mathrm{m}$, ends pointed, lumina ellipsoid, not surrounded by a gelatinous layer.

Chemistry. Thallus UV-, K-; pseudostroma exterior $\mathrm{K}+$ red, inside $\mathrm{K}+$ red. TLC: parietin, emodin and two derivatives.

Ecology and distribution. On bark of trees in plantations or along the road. Known only from Vietnam.

Molecular data. The ITS barcode is provided for the holotype CG3052 (GenBank no. KU179797) as well as the additional material: CG3042 (KU179795), CG3043 (KU179796) and CG3054 (KU179798).

Discussion. This species resembles T. subeluteriae in organization and colour, but differs by the generally lower pseudostromata and the smaller ascospores with fewer septa.

Other specimens examined. Vietnam: Western Highlands: Dong Nai Province, Cát Tiên National Park, $6 \mathrm{~km}$ south-west of the accommodation area, near a ranger house, 2012, C. Gueidan 3042, 3043 (BM, VNMN); $10 \mathrm{~km}$ south-west of the accommodation area, near the minority village, 2012, C. Gueidan 3054 (BM, VNMN).

\section{Viridothelium inspersum Aptroot sp. nov.}

MycoBank No.: MB 815249

Viridothelium with solitary, immersed ascomata and an inspersed hamathecium, ascospores 12-14-septate, 60-75 × 12-17 $\mu \mathrm{m}$.

Type: Papua New Guinea, Central Prov., along Hiritano Highway, $50 \mathrm{~km}$ NW of Port Moresby, $5 \mathrm{~km}$ NW of Brown River, alt. $25 \mathrm{~m}$, February 1987, A. Aptroot 17317 (ABL-holotype).

(Fig. 7D)

Thallus corticate, smooth, somewhat shiny, continuous, covering areas $\leq$ at least 
$7 \mathrm{~cm}$ diam., c. $0 \cdot 1 \mathrm{~mm}$ thick, olive-green, prothallus not observed, not inducing gall formation of the host bark.

Ascomata globose, 0.5-0.8 mm diam., single, deeply immersed in the bark below the thallus, without discernible pseudostromata. Wall brown, not always all around, $\leq c$. $50 \mu \mathrm{m}$ thick. Ostioles apical, convex, brownish grey. Hamathecium inspersed with oil globules. Asci with 8 ascospores. Ascospores hyaline, fusiform, 12-14-septate, 60-75× $12-17 \mu \mathrm{m}$, ends pointed, lumina ellipsoid, not surrounded by a gelatinous layer.

Chemistry. Thallus and pseudostromata UV-, K-. TLC: no secondary substances detected.

Ecology and distribution. On smooth bark of trees in rainforest. Known only from Papua New Guinea.

Discussion. This is the only Viridothelium with solitary, immersed ascomata and an inspersed hamathecium.

\section{Viridothelium kinabaluense Aptroot sp. nov.}

MycoBank No.: MB 815250

Viridothelium similar to $V$. indutum (Stirt.) Aptroot \& Lücking with emergent black ascomata, but with 17-25septate ascospores of 100-150 × 18-23 $\mu \mathrm{m}$.

Type: Sabah, Mount Kinabalu, along summit trail, alt. $2800 \mathrm{~m}, 12$ May 1998, H. F. M. Sipman $\mathcal{E}$ B. Tan 31226 (B-holotype).

(Fig. 7E)

Thallus corticate, smooth, somewhat shiny, continuous, covering areas $\leq$ at least $7 \mathrm{~cm}$ diam., c. $0.1 \mathrm{~mm}$ thick, olive-brown, surrounded by a $0.3 \mathrm{~mm}$ wide black prothallus line, not inducing gall formation of the host bark.

Ascomata globose, 0.6-1.0 mm diam., single, emergent from the bark and from the thallus, often largely exposed, black, without discernible pseudostromata. Wall black, $\leq c .100 \mu \mathrm{m}$ thick. Ostioles apical, concave, brown. Hamathecium not inspersed with oil globules. Asci with 4 ascospores. Ascospores hyaline, fusiform, 17-25-septate, occasionally with a longitudinal septum, 100-150 $\times$ 18-23 $\mu \mathrm{m}$, ends pointed, lumina ellipsoid, not surrounded by a gelatinous layer.

Chemistry. Thallus and pseudostromata UV-, K-. TLC: no secondary substances detected.

Ecology and distribution. On smooth bark of trees in mountain forest. Known only from Sabah.

Discussion. This species is similar to $V$. indutum, but that species has smaller ascospores $90-105 \times 12-16 \mu \mathrm{m}$.

Additional specimens seen. Sabah: same as type, H. F. M. Sipman $\mathcal{G}$ B. Tan 31255 (B); Mount Kinabalu, along summit trail, alt. $2800 \mathrm{~m}, 1989, H$. F. M. Sipman E B. Tan 31292 (B).

\section{Viridothelium solomonense Aptroot sp. nov.}

MycoBank No.: MB 815251

Viridothelium with ascomata with lateral, partly fused ostioles and black clypeus, ascospores 15-19-septate, $75-98 \times 17-20 \mu \mathrm{m}$.

Type: Solomon Islands, Santa Isabel Island, Tanabuli Island, near Tatamba, 1965, D. F. Hill 11040 (BMholotype; $\mathrm{ABL}$-isotype).

(Fig. 7F)

Thallus yellowish brown, smooth, thin, absent (probably abraded by the harsh sea winds) over large stretches.

Ascomata mostly simple, a few aggregated with fused ostioles, emergent from the bark and the thallus, becoming fully exposed. Pseudostromata in the normal sense absent, but a carbonized clypeus is present. Wall black, $\leq 80 \mu \mathrm{m}$ thick. Ostioles lateral. Hamathecium not inspersed with oil droplets. Ascospores hyaline, fusiform, 15-19-septate, 75-98 $\times$ $17-20 \mu \mathrm{m}$, ends pointed, with ellipsoid lumina.

Chemistry. Thallus UV-, K-. TLC: no secondary substances detected. 
Ecology and distribution. On smooth bark of trees in coastal rainforest. Known only from the Solomon Islands.

Discussion. Unique in the family owing to the partly fused ascomata with lateral ostioles and black clypeus. This species looks like, and has an ascoma structure similar to, a Pyrenula sp. with lateral ostioles. The hamathecium filaments are, however, thin and anastomosing, and the ascospores remain hyaline.

The collectors of the various specimens are thanked for providing access to the material. Harrie Sipman is especially thanked for putting his valuable collections at our disposal and allowing us to describe the novelties. The Natural History Museum in London is thanked for research and travel funds to C. Gueidan and the Vietnam National Museum of Nature in Hanoi for organizing the fieldwork. We are grateful to The Stichting Hugo de Vries-fonds for travel support to A. Aptroot. Leo Spier is thanked for performing thin-layer chromatography.

\section{REFERENCES}

Aptroot, A. \& Cáceres, M. E. S. (2014) A revised species concept in the tropical microlichen genus
Polymeridium (Trypetheliaceae) doubles the number of known species, with a world key to species. Nova Hedwigia 98: 1-29.

Aptroot, A. \& Lücking, R. (2016) A revisionary synopsis of the Trypetheliaceae (Ascomycota: Trypetheliales). Lichenologist 48: 763-982.

Aptroot, A., Lücking, R., Sipman, H. J. M., Umaña, L. \& Chaves, J. L. (2008) Pyrenocarpous lichens with bitunicate asci. A first assessment of the lichen biodiversity inventory in Costa Rica. Bibliotheca Lichenologica 98: 1-162.

Lücking, R., Nelsen, M. P., Aptroot, A., Barillas de Klee, R., Bawingan, P. A., Benatti, M. N., Bungartz, F., Cáceres, M. E. S., da Silva Canêz, L., Chaves, J.-L. et al. (2016) A phylogenetic framework for reassessing generic concepts and species delimitation in the lichenized family Trypetheliaceae (Ascomycota: Dothideomycetes). Lichenologist 48: 739-762.

Nelsen, M. P., Lücking, R., Aptroot, A., Andrew, C. J., Cáceres, M. E. S., Rivas Plata, E., Gueidan, C., da Silva Cañez, L., Knight, A., Ludwig, L. R. et al. (2014) Elucidating phylogenetic relationships and genus-level classification within the fungal family Trypetheliaceae (Dothideomycetes: Ascomycota). Taxon 63: 974-992.

Orange, A., James, P. W. \& White, F. J. (2001) Microchemical Methods for the Identification of Lichens. London: British Lichen Society.

ZenkerJ. C. (1829) Kryptogamische Parasiten auf officinellen Rinden. In Pharmaceutische Waarenkunde (E. Schenk, ed.): 109-200. Eisenach: Bäreck. 